“TOLERATED” AND NON-STATUS PERSONS' ACCESS TO MENTAL HEALTH SUPPORT SERVICES: A COMPARISON BETWEEN TORONTO, CANADA AND AACHEN, GERMANY

by

Avery Toppan, Honours BSW, York University, 2010

\author{
An MRP \\ presented to Ryerson University \\ in partial fulfillment of the requirements for the degree of \\ Master of Arts \\ in the Program of \\ Immigration and Settlement Studies
}

Toronto, Ontario, Canada, 2013

(C)Avery Toppan 2013 


\section{AUTHOR'S DECLARATION FOR ELECTRONIC SUBMISSION OF A MAJOR RESEARCH PAPER (MRP)}

I hereby declare that I am the sole author of this MRP. This is a true copy of the MRP, including any required final revisions.

I authorize Ryerson University to lend this MRP to other institutions or individuals for the purpose of scholarly research

I further authorize Ryerson University to reproduce this MRP by photocopying or by other means, in total or in part, at the request of other institutions or individuals for the purpose of scholarly research.

I understand that my MRP may be made electronically available to the public.

Avery Toppan 


\title{
“TOLERATED” AND NON-STATUS PERSONS' ACCESS TO MENTAL HEALTH SUPPORT SERVICES: A COMPARISON BETWEEN TORONTO, CANADA AND AACHEN, GERMANY
}

\author{
Avery Toppan \\ Master of Arts, 2013 \\ Immigration and Settlement Studies \\ Ryerson University
}

\begin{abstract}
Using the theoretical framework of Identity Formation, this Major Research Paper (MRP) aims to explore the Post-national rights of "tolerated" or undocumented persons in Toronto and Aachen, and their access to necessary mental health services. The assumption is that the experiences of these groups are both traumatic and unique, often creating emotional, mental and physical stress. These forms of stress require various forms of treatment, from formal mental health evaluations, to informal group counselling or bonding with persons of similar experiences. This work takes three service providers in each city, discusses the perspectives and services available, and offers an analysis as to whether they provide the suitable and necessary care for "tolerated" or non-status persons. I will argue that social exclusion in the form of contestant enmity is utilized to deny full access to support services. Recent legal and policy changes in both countries will be accounted for, and recommendations given as to how the service providers and actors at the municipal level can move forward to provide the necessary services.
\end{abstract}

Key Words: Identity Formation Theory; supportive mental health; "tolerated" persons; nonstatus persons; Germany; Canada 


\section{ACKNOWLEDGEMENTS}

I would like to thank all of the people who took the time to speak to me, to help me to get an understanding of services that their organizations offer, and their passion for the incredible work that they do. Their kindness and patience (especially with my German) is much appreciated.

Unlimited thanks to my supervisor Harald Bauder, whose speedy responses and thorough and thoughtful commentary on this MRP were extremely helpful in shaping the final product and encouraging me to explore my ideas more deeply. And to my second reader Mandana Vahabi, whose insights into the medical perspective and enthusiasm assisted me to create a more wellrounded and thorough project.

Lastly, a huge thank you to my family and friends - both in Canada and Germany - who encouraged and supported me throughout the sometimes daunting and stressful writing process. As well as those close to me who provided insight and important direction in navigating current German research and resources. Frigga, your assistance went above and beyond - I cannot thank you enough. 


\section{TABLE OF CONTENTS}

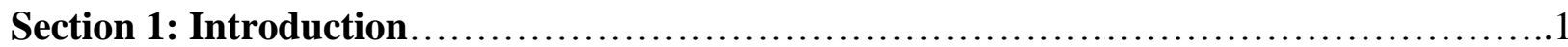

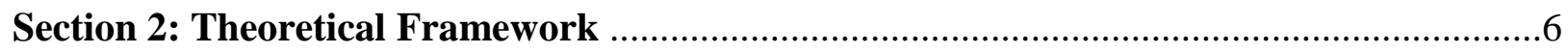

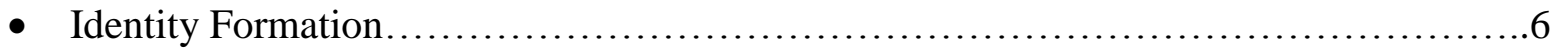

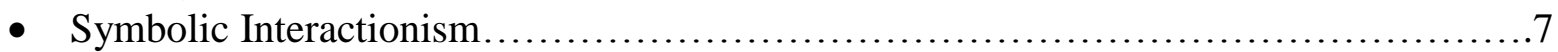

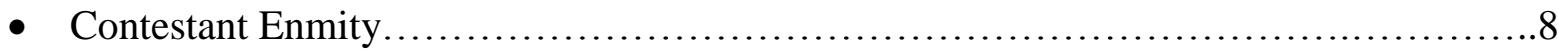

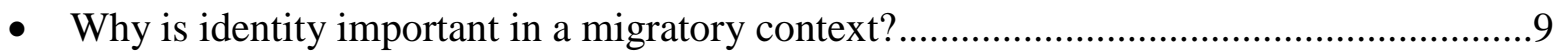

Section 3: Canadian and Torontonian Context......................................... 10

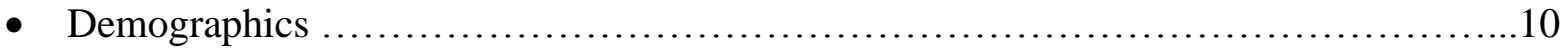

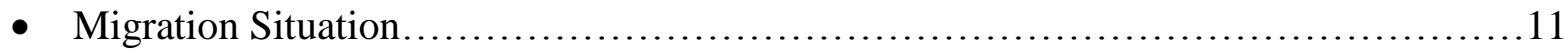

- Asylum Process: Legalities and Realities......................................... 11

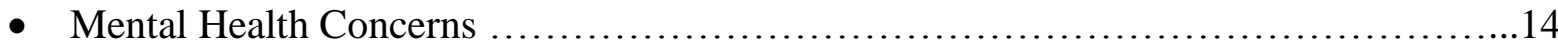

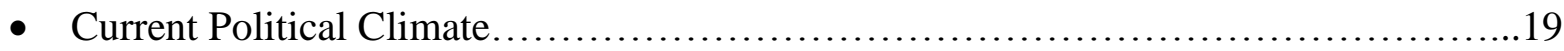

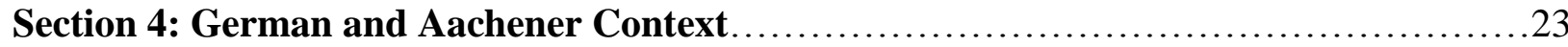

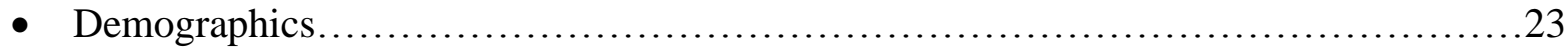

- Migration Reality \& Anti-Immigration Sentiment....................................26

- Asylum Process: Legalities and Realities...............................................

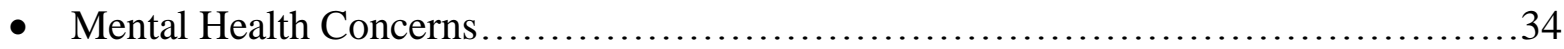

- Political Climate: Süssmuth's Recommendations \& her Critics.............................37

Section 5: Service Provider Analysis....................................................... 41

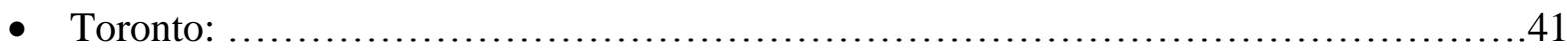

○ Canadian Centre for Victims of Torture ...................................42

○ Newcomer Centre of Peel....................................................43

$\circ$ Becoming Neighbours.......................................................... 44

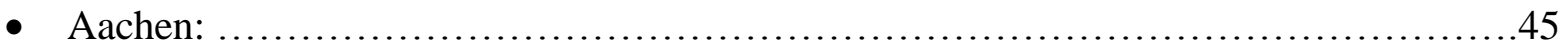

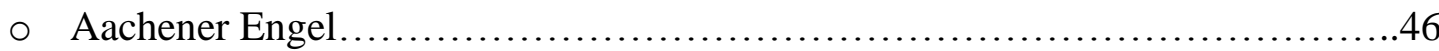

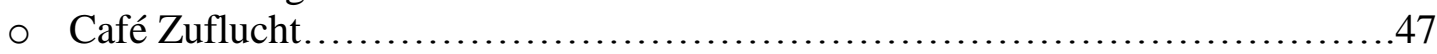

○ Pädagogische Zentrum Aachen...............................................49

- Similarities and differences in service delivery ....................................51

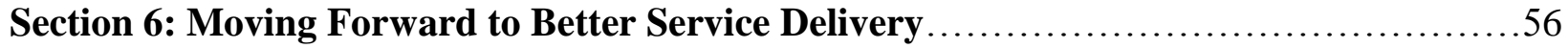

- Recommendations - What can the municipalities learn from each other?..........................56

- Importance of acknowledging Identity Formation....................................59

- Combatting municipally negative images of precarious migration......................60

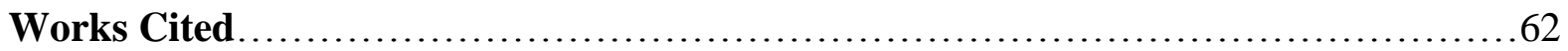




\section{List of Figures:}

Figure 1: Entries into the GTA by type of Temporary Residency..........................13 


\section{Section 1: Introduction}

This MRP begins from a grounding placed firmly in the belief that the migratory process under any circumstances is a difficult and obstacle-filled transition. This truth is exaggerated for those who are forced to migrate due to traumatic or uncontrollable circumstances, such as refugees. These migrants are forced to navigate an often confusing or hostile system, while simultaneously testing their coping mechanisms in an adjustment period that frequently places much emphasis on the individual migrant to conform, integrate and succeed. Much of the attention in regards to newcomers appears to be focused on the economic or linguistic integration so as to create the quickest turnover that would allow these migrants to become functioning and contributing members of the new society (Soysal, 2012; Birg; 2010; Statistics Canada, 2006). Yet with this focus on host society gain, the human perspective of newcomers as struggling new members is sorely lost. This work takes aim at what is arguably the most vulnerable migratory position to be in - precarious or non-status. This terminology refers to migrants whom, for various reasons, are living within a city without legal status or official documents. This MRP is unique in the sense that it involves an international and cross-cultural comparison and analysis, between Toronto, Canada and Aachen, Germany. These two countries were chosen for comparison due to their oppositional nature in terms of acceptance of an immigrant receiving national identity, and their affinity with accepting a multicultural approach to immigration and populations. Germany has only recently began to adopt changes that accept the shift from a national identity based upon "Germanness" to one of an immigrant receiving nation, that would thus need to adapt and work with newcomers to redefine itself (Wendland, 2011). Canada on the other hand has a long-standing history based upon immigrant and the settlement of peoples from all around the world - beginning mainly with Europe and developing overtime to source countries from Asia and the Middle East. Canada is characterized as a settler-society, which 
officially claimed Multiculturalism as an identity in 1971, and has despite somewhat hostile attitudes regarding the "right type of migrant", has no issue accepting its identity as a target for immigrants and a land comprised of peoples from many nations - who come together to define what Canada is (Bauder, 2011). It is this dichotomy that makes Canada and Germany extremely interesting developed nations to compare in terms of their approach and self-definition regarding migrants currently within the borders as well as future migration schemes. Due to the variations of legal definitions and asylum procedures, the categories of 'precariousness' in the respective countries differ. As will be discussed further in greater detail, the majority of peoples within these categories arrive in such a position as a result of a failed asylum claim. The difference between nations here is evident, as Germany allows for a more formalized category of "tolerated" for circumstances in which deportation is not feasible or inhumane (Schuehrer et al., 2013), whereas the Canadian context creates a much more precarious and informal position, where over-stayers and denied applicants slipping between the bureaucratic cracks are a common occurrence (Uniya Jesuit Social Justice Centre, 2013). Canada does have admission based on humanitarian grounds, or protection which is similar to that of the "tolerated" status. However the shared obstacles in access to care and services, and precarious postionality within the receiving city, make Toronto's non-status and Aachen's “tolerated” peoples more comparable.

Despite the legal and formal differences in creating this population, the fact is that they exist and become parts - whether more visible or invisible - of both societies. This MRP aims to focus in on the municipal level - Toronto and Aachen - to see the ways in which they are, or fail to address the needs and concerns of the vulnerable "tolerated" or non-status peoples within their jurisdictions. Duty of care is of extreme importance, as I recognize that the migratory process in general, but especially upon this group, creates strain on the mental health and coping 
mechanisms of newcomers that is unique in the way it occurs and manifests itself. The stress, anxiety and natural depressive feelings that accompany such movements also challenge the process of identity formation and sense of self or belonging - thus in this context, it forces migrants' identities to be in flux as well as constantly tested throughout their transition period. From these grounding beliefs arose the guiding research question of, how are these cities adapting services to meet the needs of this vulnerable population? Therefore the aim was not to dissect whether the overarching policies or legal frameworks guiding the realities of asylum seekers were necessarily correct or not - but rather how effective are the reactions of the local service providers whose responsibility it is to care for the needs of the community in ways that higher levels of government are incapable of doing. Local service providers, as argued by Bhuyan (2011) are equipped with tangible opportunities to advance the human rights of individuals, regardless of status. Furthermore, these local agencies are uniquely positioned to do so (Bhuyan, 2011). The local level provides individual care in a crucial way that must be recognized for its importance and power. Thus, this MRP will explore how the service providers present at the municipal level are interpreting policy and mandates, to create a broader approach of the ways in which the city is adapting and recognizing the mental health needs of "tolerated" and non-status peoples.

Site visits to three service provider organizations in Toronto, and three in Aachen, created the ideal way to assess the agencies not only through publically available information, brochures and annual service reports, but also through personally seeing the location, staff and nature of the organization itself. As a result of not having the proper ethics clearance for the conducting of personal interviews in Germany, the selected methodology did not allow for any private information differing from what is available to the public. Therefore all analysis and comments 
are based on the documents published by the organizations, accessible internet information, and conversations with staff which did not stray from publically available knowledge about the service provider's mandate, funding sources, programs offered and their structure, as well as numeric data such as attendance and demographics of service users. The limitations of this approach are thus that important insight from frontline workers and those in the field were unable to be included, which would have provided a beneficial perspective not offered through only second-hand data. The perspectives of service providers in regards to how national and municipal policy is affecting their practice, if at all, is also sorely lacking as a result of this approach. Detailed analysis as to whether city action plans are effective is unfortunately inadmissible, as are any comments staff made regarding personal opinions on the "bogus" or illegalized migrant public discourse. Some data gained in the Canadian context was done through public speeches given by certain service providers, in which management discussed the aforementioned topics. Discussions with staff regarding publically available information conducted in Germany, were done so in German.

In terms of locating myself in my research area of interest, I am not, nor do I have a personal connection with someone of the experience of "tolerated" or "non-status" categories. My initial interest came from my background in social work, and heightened awareness of healthy mental states and depression - as I experienced migrating to Germany for personal interests. After initially struggling with learning the language and adapting to the German mentality in terms of immigration and what it means to be a 'foreigner', I quickly became aware of how easily one can become isolated and trapped with feelings of un-belonging, depression and more importantly to this work, loss of one's sense of self and identity. I had entered this experience with confidence regarding my academic and professional abilities - and was faced 
with harsh opposition in a fierce and strict German system that required integration and linguistic conformity from me. With time, learning the language was not a problem, but through this process, for the first time in my life, a white middle-class woman felt like a complete outsider, and an unwanted, easily cast-away non-member of this society. Gradually I was able to feel slowly integrated, but it raised the question of how difficult and crisis inducing this procedure must be for those without my physical and educational privilege. Also, I had personal connections to assist with the transition which I also quickly found out was of the utmost importance in the German context, which privileges "Vitamin B" ("B" referring to Beziehungen or connections, i.e. having the right networks or relationships). Through my own personal interest and research, the category of "tolerated" came to my attention, which clearly mirrors the undocumented status present within Canada, and from this point my passion for the mental health rights and care for vulnerable peoples blossomed. Further, I find myself extremely interested in the ways in which Germany is slowly recognizing its role as an immigrant receiving nation - and this work builds upon this pubescent-like identity formation in hopes of providing recommendations from the Canadian context, which is more adept and experienced with multiculturalism and immigration flows. I am not German and the language is not my mother tongue. All knowledge of German was gained through several intense language courses, personal dedication and much time spent in Germany. Data used for this MRP was written in both English and German, therefore German research was interpreted by myself personally, as well as all German translations present within this work. 


\section{Section 2: Theoretical Framework}

Identity formation theory is useful in the context of migration in the way in which it specifically focuses on an individual's perception of themselves - and more specifically, the way in which the 'self' is created out of the interpretation of interactions within society (Cinoğlu \& Arikan, 2012). The sociological understanding of the self and one's identity starts with the presupposition of a reciprocal relationship between the self and society, and highlights the way that society holds a power over the self - imposing change on the individual depending on their position or perceived position within the larger society (Cinoğlu \& Arikan, 2012). This is especially crucial during the asylum process, where the future of the individual and their family is decided by the powers of the governing system in each respective country. It is further examined by Bauder (2011) who identifies this process as a dialectical relationship between the imagined national identity of the collective self (the nation), and the foreigners who are viewed to not belong. Theories of identity appear to agree on one main starting point - the self and identity are composed of a variety of component parts, a fragmentation in the contemporary world (Serpe \& Stryker, 2011; Cohen, 2006; Cinoğlu \& Arikan, 2012). Symbolic Interactionism - a separate branch of identity formation theories, holds further relevance in the way it not only takes into account society as a whole, but rather looks to micro and individual level interactions as holding meaning in the self-categorization of the roles expected or internalized by the individual. In other words, how one is "learning to become the individual that his or her group wants them to be" (Cinoğlu \& Arikan, 2012). Here, one can see several key issues that directly reflect the experiences of newcomers, specifically those whose culture or norms may differ from the receiving society, in this case, Toronto and Aachen. As explained by these theories one can understand how the negative or positive reactions by current community members or the 
structures within the city can create an immediate sense of belonging and acceptance, or an 'othering' that forces the identity to be in direct conflict with the expected norm. This is exemplified by potentially confusing and negative interactions between non-status or "tolerated" peoples and formal city structures such as the foreigner's office - something discussed further on as being a main point of advocacy amongst service providing organizations for this group.

Symbolic Interactionism will be utilized throughout the analysis of service providers, but more so in the argument depicting why mental health services for "tolerated" or non-status peoples is of the utmost importance. Serpe and Stryker (2011) highlight that meanings develop in the interaction itself, and that humans develop self-conceptions about who and what they are, shaped by the social process and by entering into that process. This theory of identity formation is especially useful in the way in which it pinpoints self-definition - as this work maintains that it is the definition or view of oneself that is altered and constantly in flux throughout the migration process. The way in which this group, even deriving from their less than welcoming title of "tolerated", view themselves dialectically with the responses and reactions of others in their surroundings, is what creates a crisis of identity, meaning and purpose of life, and belonging in the new community (Serpe and Stryker, 2011).

Individual agency is also mentioned, in regards to when the individual realizes that they cannot change the pre-existing structures or behaviour patterns, but instead can change their behaviours to fit within the borders of these structures (whether they be bureaucratic, social or economic) (Cinoğlu \& Arikan, 2012). Again, it isn't very difficult to move from these theoretical explanations, to the more tangible lived realities of the refugee or asylum seeker narrative. Refugees or non-status peoples face specific hardship in this respect, as they are often directly in conflict with what many people would consider the 'normal' migration route - hence the often 
used phrase of 'bogus refugees' or 'queue jumpers' (Bradimore \& Bauder, 2011). These derogatory terminologies take the individual, or human being, out of the equation and rather immediately juxtapose them against what the idealized 'normal' Canadian or German migrant should be. This could be considered an "out-group" mentality as defined by Identity Formation Theory as being the natural way in which those expressing alternative or 'abnormal' behaviours will be perceived as non-members (Cinoğlu \& Aiken, 2012). This reflects the identity theory premise put forth by Serpe and Stryker (2011) which outlines that society influences the self, which in turn creates the social behaviour exhibited. Building upon this notion of in and out groups, Stets and Burke (2003) claim that all individuals, in all of their dealings, try to verify their existence. Therefore if that were true, "tolerated" peoples or non-status migrants who are subconsciously or blatantly being positioned as the other or out-group in the municipal setting, are faced with further marginalization and difficulty while attempting to overcome potential past traumas (push factors from home) as well as transitioning into the municipal community. When the very city that is meant to be a safe haven, is placing a negative identity upon migrants from the beginning - one can see that both the coping mechanisms as well as one's ability to maintain strength and healthy mental capabilities could be severely strained.

The last component of identity formation that will be utilized in the analysis of the asylum seeker process and mental health service, is a form of social exclusion referred to by Cohen (2006). "Contestant enmity" coincides strongly with the experiences of this group, as it is a form of antagonism and hatred generated by social practices of identity seeking and boundary drawing. It seeks to dramatically separate groups and keep a required distance from one another. This separation is deemed necessary because the 'alien' threatens to penetrate opposing groups or blur the distinction between familiar and strange (Cohen, 2006). It will be argued that 
"contestant enmity" is the driving force behind the interactions between "tolerated" or non-status peoples, and their respective receiving societies. It serves as the foundation that creates stressful or painful interactions resulting identity fragmentation or a loss of one's sense of self - often in favour of the absorption of the group or nation state identity or in isolation and segregation in an act of self-protection.

When depersonalization - the loss of self in favour of group existence - is the requirement for migrants and newcomers alike, mental health services become crucial and the lack of services or access for these vulnerable groups is therefore highly problematic. As will demonstrate in the following sections, often confusing processes await asylum seekers in both Canada and Germany. Further to the point of "contestant enmity", the conditions awaiting arrivals of asylum seekers is often less than welcoming. Governments are increasingly shifting towards the marketing and recruitment of highly qualified migrants, while simultaneously pushing the specific needs of these vulnerable groups to the backburner, and ignoring the profound potential existing within the group. Moving forward from this foundational understanding of Identity Formation Theory and the socially exclusionary practice of "contestant enmity" - the specific migratory composition in the Toronto and Aachen contexts needs to be examined. 


\section{Section 3: Canadian and Torontonian Context}

\section{Demographics:}

Toronto and its Census Metropolitan Area (CMA) is within the top three major gateways for immigrants and newcomers to Canada, especially with a foreign-born population reaching over 2.3 million (Statistics Canada, 2006). This number is the largest in the nation, giving the appearance of a well-equipped and settlement oriented municipal structure. Demographics available from the 2006 Canadian census reveal that the foreign-born population grew $14.1 \%$ between 2001 and 2006 compared to a meagre 4.6\% of Canadian-born counterparts (Statistics Canada, 2006). The fact that Toronto is clearly comprised of such a large migrant population may have reactive effects in the lure for newcomers to join with others of their ethnic group, family and friends, or those who have experienced similar traumas and know the strains of migration. Potential reasons aside, 4 out of every 10 immigrants to Canada settle in the Toronto CMA, with the main source country being India followed closely by China. Narrowing down from the general immigrant classification to look at recent newcomers, the data shows that 267,000 , or $1 / 5^{\text {th }}$ of the total influx, settled in Toronto (Statistics Canada, 2006). Federal government statistics continue to express the economic utility of these migrants, by explicitly highlighting the fact that $56.6 \%$ of newcomers were within prime working age (25-54), while alluding to their main barrier of economic success being the lack of English through the mention of the fact that only 24\% spoke English (Statistics Canada, 2006). These findings are important because they give a general overview of the composition of Toronto as well as highlighting the desirability of the large metropolitan area (and surrounding suburbs such as Mississauga or Markham) for newcomers. However this data falls short of looking more specifically at the 
precarious and undocumented populations that are most likely not accounted for in official Federal statistics.

\section{Migration Situation:}

No One is Illegal fills this gap by discussing the exploitative temporary workforce and estimating that in 2008 roughly 300,000 or more workers in Canada entered work arrangements of this variety (No One Is Illegal, 2012). What is specifically important in relation to this work and looking at the mental health access and outcomes for newcomers, is the estimation of over 500,000 non-status and peoples with precarious status within the city or GTA, living and contributing in their own ways without access to official employment or health care (No One Is Illegal, 2012). The unavailability of official numbers or quantitative research in the area of nonstatus peoples within Canada as a whole, make this issue extremely difficult to probe and to advocate on their behalf for equal access or rights; as well as to have tangible, empirical data to complement theoretical research (Goldring et al., 2007). This lack of data is a result as previously mentioned, of not having a formal category such as "tolerated" where rejected asylum seekers are, thanks to some loopholes and clauses within the legal framework, permitted to stay

in the country until further notice (City of Toronto Report, 2012). The asylum procedure in Canada will be outlined so as to give a greater understanding, and to make the comparison between this process and that of Germany.

\section{Asylum Process: Legalities and Realities}

The asylum seeking procedure in Canada allows for those seeking refuge to apply once arriving in Canada, either at a land border or in the airport of arrival (Uniya Jesuit Social Justice Centre, 2013). However the Safe Third Country agreement between Canada and the United 
States dictates that asylum seekers passing through a designated safe country, such as the United States, cannot claim refuge in Canada, as they should apply within the first safe country to which they arrive (Uniya Jesuit Social Justice Centre, 2013). This extends to sea arrivals, where in most of these cases boats are either turned away upon arrival or passengers are immediately detained for processing (Uniya Jesuit Social Justice Centre, 2013, City of Toronto Report 2012). On this note, the detention of asylum seekers is also generally on the rise in Canada, which shows an inclination towards following trends already present in both the United States and Australia (Uniya Jesuit Social Justice Centre, 2013). However since the implementation of the Safe Third Country agreement on December $29^{\text {th }}, 2004$, City of Toronto officials note a shift in less land arrivals in favour of the increased usage of other visas to permit entry, and then a trend of simply overstaying said visa. Thus creating a grey area where the migrant is forced to live under the radar as an undocumented or non-status person only permitted to work illegally (City of Toronto Report, 2012). Immigration officials at the border have three days to decide whether an asylum seeker is eligible to make a claim for protection (Elgersma, 2008). Once a claim for refuge has been put forth, the waiting process begins. While awaiting a decision, the asylum seeker is considered a Temporary Resident and would be documented as such. This waiting period can differ for individual circumstances, and this procedure differs depending on country of arrival, specifically after the recent implementation of Bill C-31, which reduces the amount of time one has to prove one's claim from the previous 60 days, to the current 30 day period (City of Toronto Report, 2012). This is a result of the inherent belief that certain countries cannot produce legitimate refugees and therefore the shortened time-period is a deterrent and motivator for those who may be sincere, to get their paperwork and proof together in a timely and efficient fashion to 
please the governmental requirements. The claimants from these source countries have no right to appeal upon rejection of the claim (City of Toronto Report, 2012).

Moving forward from the position of a rejected claim, Canada's lack of exit controls allow for an unknown number of over-stayers beyond this process, as many are assumed to have left by the date dictated on their deportation notice (Uniya Jesuit Social Justice Centre, 2013). Rejected asylum seekers lose their status of Temporary Resident upon the rejection of their claim (City of Toronto Report, 2012) - to put this into a tangible context, the 2004 figures show that 40,408 claims were rejected in Canada, with an acceptance rate of $40 \%$. Of the $60 \%$ rejected, the city of Toronto (2012) notes that not all failed claimants were returned immediately due to appeals processes, a lack of documents on the part of the migrant, or a failure to appear. Therefore the whereabouts for most of this group is unknown. There is a "protected" category which is similar to that of "tolerated" migrants in Germany, which allows the few failed asylum seeker applicants to stay within Canada until a specified date, however they must come from one of the designated unsafe countries which include, Afghanistan, Burundi, the Democratic Public of Congo, Haiti, Iraq, Liberia, Rwanda and Zimbabwe (Elgersma, 2008). In terms of over-stayers becoming potential non-status peoples, the figures of temporary residents gain importance, as one can thus assume that many people looking to evade the Safe Third Country agreement, and following the previously highlighted trend of opting for temporary or student visas and simply over-staying, would be included in the current Temporary Resident figures (Figure 1).

The City of Toronto reported 54, 610 temporary residents in the 2006 census (City of Toronto Census, 2013). This number increased in 2011 to 57, 729, which represents $18 \%$ of the total Canadian number (City of Toronto Census, 2013). With no large scale efforts in the works, to collect data about individuals without migratory status, City of Toronto officials assume 
roughly $50 \%$ of the total population in this category in Canada to be living within Toronto (City of Toronto Report, 2012). These official figures differ from those highlighted by No One is

\section{Figure 1: Entries into the GTA by type of Temporary Residency}

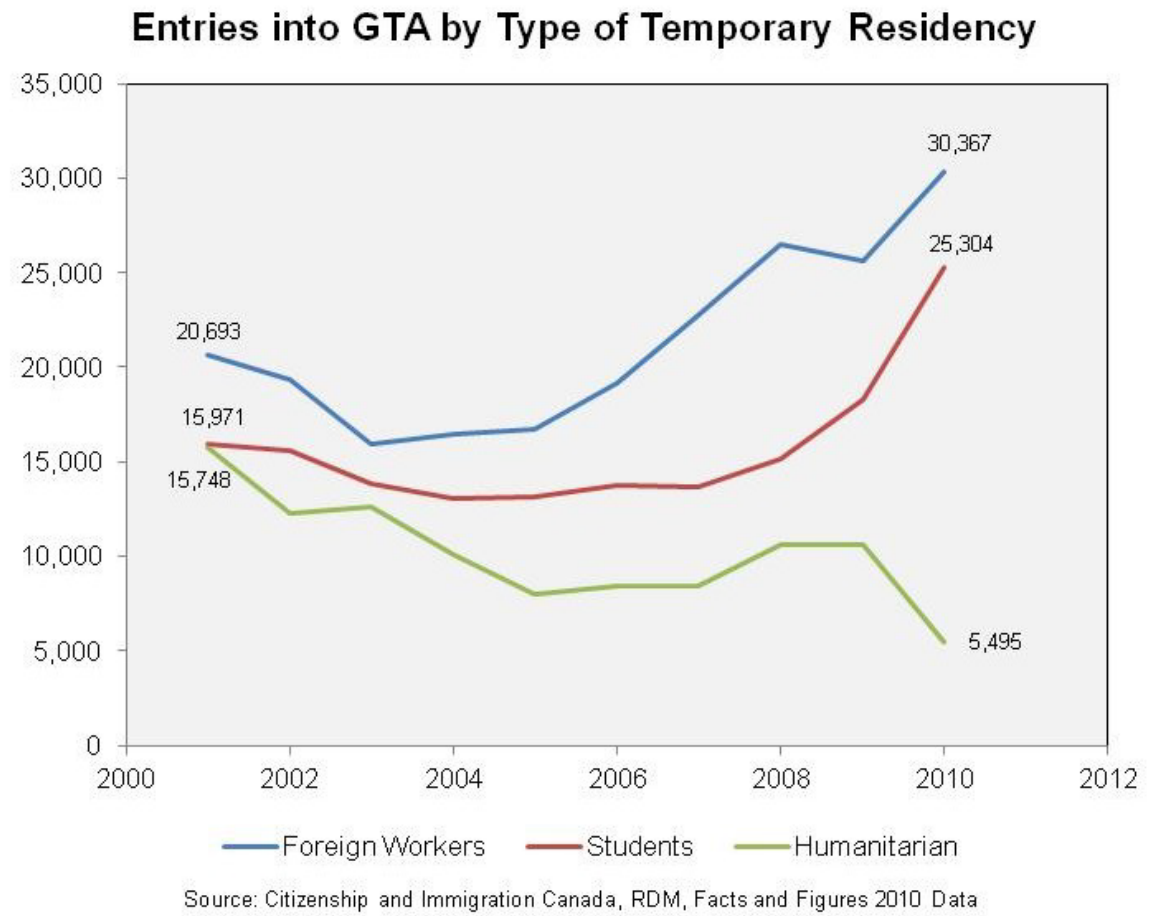

Source: City of Toronto Report, 2012

Illegal which further exemplifies the lack of consensus and general gaps of information regarding such an at risk population.

\section{Mental Health Concerns:}

Lack of communication and coordination between levels of government and services, as well as an informal and relatively chaotic system which places much emphasis on the individual to adhere to deportation orders, creates an easy transition into extremely precarious situations for non-status peoples. As described above, the failed asylum seeker route, or the route of an overstayer, are the two main ways in which people fall between the bureaucratic cracks in the system, 
and enter into a vulnerable position of being non-status within Canada, and specifically in the city of Toronto. As displayed through the work of organizations such as No One Is Illegal, the majority of emphasis is placed upon creating equality by officials and policies in the sense of either regularization programs or giving access to employment and health services. Here we see a perception of health care that does not explicitly state mental health or counselling services something that appears to take a back-seat to other pressing and immediate concerns for such an exploited, marginalized and ostracized group of people. The invisibility of this group make it extremely difficult to know specifically what their needs are. However the city of Toronto recently admitted that in the context of undocumented workers - which in this case can be extended to non-status or precarious migrants in general - signs of persistent trauma, depression, anxiety and chronic stress are often present (City of Toronto Report, 2012). Further to this point, a November 2011 Toronto Public Health report stated that undocumented newcomers face unique and serious health issues, along with many barriers in access to services (Board of Health, 2011). For the sake of clarity in the upcoming examination of mental health services in Toronto, this work understands "mental health" according to the World Health Organization's 2007 definition of,

"a state of well-being in which the individual realizes his or her own abilities, can cope with the normal stresses of life, can work productively and fruitfully, and is able to make a contribution to his or her community" (Mckenzie et al., 2009).

This definition is repeated within contemporary research in this area, as Khanlou (2010) reflects the symbolic interactionist approach taken by this MRP, by stating that this state of wellbeing arises from interactions between the individual and his or her environment. This is reflective of 
the social process that migration itself is, and that this process, as stressful and testing as it may be, becomes a significant determination of health outcomes (Khanlou, 2010; Fenta et al., 2006). Involuntary immigrants, the terminology to refer to those migrating out of emergency or necessity - asylum seekers as understood by the author - often experience very difficult transitions and require frequent medical care (Fenta et al, 2006). Studies looking specifically at Canada's younger refugees find high levels of distress and depression, and highlight as well that refugees fleeing war or torture situations are at a substantially higher risk than the general population for various psychiatric disorders, and time times higher rates of post-traumatic stress and elevated rates of depression (Kirmayer et al., 2011).In fact, exposure to torture is the strongest predictor of symptoms of post-traumatic stress among refugees (Kirmayer et al., 2011). Yet people without official status are not entitled to, or receive limited access to publically funded health care and social services (Goldring et al., 2007). This idea is mirrored in Khanlou (2010)'s discussion, supported by Goldring et al., (2007), of the systemic barriers that non-status or precarious migrants in Canada face, as health care and social services are extremely limited and reflective of marginalization in the way in which it creates a critical dimension of exclusion. Canada as a whole, as well as municipalities such as Toronto do indeed recognize the existence of this population, despite it not being a formalized legal category entitled to specific employment and access rights or full medical and health benefits.

Refugees, denied claimants pre-departure and precarious peoples can access Interim Federal Health Plan (IFHP) services that encompass only 'urgent' or 'essential' services (Goldring et al., 2007). This funding comes from the Ontario Ministry of Health and Long-term Care and is dispersed amongst local community health centres, which specifically put aside a portion of funding for those without status (Goldring et al., 2007). This funding model 
recognizes the needs of precarious, non-status peoples or refugees within Toronto's boundaries, as well as acknowledging that health care services cannot be denied at a fundamental human rights level. It also allows for the provision of the "protected" peoples category to receive IFHP benefits for the duration of their acceptance in Canada, which can be years (Elgersma, 2008). Yet here one can see the strong reluctance to go further than what is required by international legal bodies or humanitarian agreements, as the limitations of the IFHP are such that mental-health services are explicitly excluded despite parliament's acknowledgement that they may be crucial for the wellbeing of traumatized peoples (Elgersma, 2008). An area of particular concern in this health plan and of importance to this MRP, are denied refugee claimants who are often trapped in limbo. This population is entitled to continue to maintain IFHP coverage as long as they file a judicial review up until their removal date (Goldring et al, 2007). It is easy to imagine that the stress and trauma that this population would feel during an unclear and socially excluded process would specifically warrant access to some sort of counselling or mental health service to address concerns, work on coping mechanisms and to ensure the safety of the individual, as worthlessness and suicidal thoughts are extremely common among depressive or frantic individuals (CAMH, 2013). Fenta et al.'s (2006) findings regarding depression among involuntary migrants uncovered higher rates than predicted, yet with only a small proportion using formal healthcare or reaching out for care in general. With reluctance from the Federal and Provincial levels to adequately address or fund mental health access or awareness, a crisis among service providers is created. As Goldring et al., (2007) perfectly articulate, precarious status equals precarious access to service, a contestant enmity of sorts. Asylum seekers and precarious migrants are in desperate need of mental health services in one form or another, yet promotion of increased service is clearly not on the agenda for government funders, and service providing 
organizations are thus disadvantaged to provide those specific services when not mandated or fiscally capable. A clash occurs - the humanitarian duty of service providers is to assist the fundamental needs of clients, yet how can this be done in such a constrained environment?

Bhuyan (2011) recognizes this need also, and raises a critique of the rapidly increasing trend to welcome migrants for economic purposes, while growing numbers of migrants are excluded from citizenship rights, and given limited access to social and health services. These restrictions on the entitlement to social care - as argued by this MRP - creates vulnerabilities which lead to negative health outcomes and deep social exclusion (Bhuyan, 2011). In her look at the role of local service providers and frontline organizations for reaching the needs of nonstatus and precarious migrants in Canada, Bhuyan brings attention to Sharma (2007) who notes that national regimes of citizenship are inherently exclusionary and produce separate legal regimes and practice for differentiated groups of people within the same national space. Despite Canada not having a formal "tolerated" category, their recognition on the federal, provincial and municipal levels of the existence and physical/mental health needs of non-status peoples within their borders, exemplifies the way in which they produce and reproduce the categories of the good and bad migrant. Through the numerous studies funded and City of Toronto reports and initiatives into this very area of concern, it becomes clear that this population is not hidden in terms of going unnoticed, but rather they continue to be hidden in terms of a strong and prominent outreach to meet these important needs. Research has clearly shown that non-status people live within the city, and are facing hardships not experienced by community members or to peoples undertaking more formal immigration routes. There appears to be no question as to whether or not the state of non-status people's mental health is affected, or that they face racism and discrimination on various levels, which inherently leads to negative mental health outcomes 
(Khanlou, 2010). Yet formalized programs to specifically address these concerns appear to be few and far between - and when evident - seem to materialize at the local or municipal level. These circumstances develop to the belief of this MRP as well as that of Bhuyan (2011), that the extension of social rights to vulnerable groups seems to have always relied on grassroots mobilization or civil society organizations. In this way, local level service providers are strategically placed in a position to address the needs that have been recognized by larger government bodies, however have not yet not been acted upon in larger policy movements or government funding programs.

\section{Current Political Climate:}

Recent political activity in the city of Toronto shows progress towards a formal recognition of non-status peoples as well as the needs that are specific to their migration experience and narrative. Touching upon Post-national citizenship is important for both the Canadian and German context of this issue. First highlighted in 1994 by Soysal, Post-national citizenship derived from the observation of increased migratory and guestworker movements throughout Europe, and the belief that citizenship rights should be extended to that population regardless of formal citizenships based on nation state boundaries (Soysal, 1994). I will argue in the context of Toronto, that Post-national citizenship is a supportive framework that assists in forming the argument of the extension of rights to the non-status people in Toronto and their specific needs. Post-national citizenship scholars would argue that national identities are a myth with an embedded objection of creating common interest and assumed rights and privilege based on nation-state citizenship practices (Tambini, 2001). The idea of these national identities being a constructed myth is echoed throughout academic work which highlights the way in which national communities are created through narratives highlighting important components of 
belonging to the state - such as shared history, language and mythology (Bauder, 2011; Wendland 2011; Winter, 2010). Post-national citizenship argues directly against the belief of a nation-state grounded citizenship based on birth or heritage, in favour of adopting a citizenship that encompasses a community level approach where those who contribute to the area where they live should thus be deemed members of that society (Sassen, 2002). Saskia Sassen (2002) further highlights the way in which Global Cities such as Toronto have unique and strategic ways in which they can push for this type of belonging by demonstrating that civic involvement and social deservedness merit legal residency or residents' rights. In other words, it is the shift from adhering to a strictly legal relationship between the individual and polity, towards a relationship between individuals and their communities (Sassen, 2002). Recent events in Toronto highlight exactly what these and other scholars are arguing in their discussion of the ways in which municipalities and Global Cities have the power to create these changes and adapt to modern approaches of citizenship.

Sanctuary Cities are such that aim to remove the fear of accessing services that non-status or undocumented peoples battle. The concept therefore acknowledges some fundamental facts, one being that non-status peoples are living within the borders of the city regardless of state intervention through curbing or punitive measures, and two, that they are indeed human beings and therefore the municipalities have the inherent duty to provide necessary services to them. The passing of this model occurred in February of 2013, and made Toronto the first Canadian city to do so - joining in with 36 American cities already committed to the plan (Keung, 2013). Essentially, it builds upon a previously utilized campaign of 'don't ask, don't tell' to encompass areas not previously guaranteed safety such as shelters or health care (Keung, 2013). Applying a Post-national perspective to this movement, it is clear that the concepts of acknowledging people 
living as non-citizens or not formally recognized by the state, as community level members with rights of their own, falls in line with the arguments made by scholars (Sassen, 2002; Bhuyan, 2011). Sanctuary City takes away the power from federal bodies such as the Canadian Border Services Agency from deporting or conducting sweeping raids in search for non-status migrants - and placed power in the hands of the local level community organizations and community health centres. It toes the line with being truly transformative in the sense that it does not address services under the provincial or federal umbrella such as housing or welfare, as well as does not take away the requirement for police to report to Immigration if they do find the person to be undocumented (Keung, 2013). However, it is extremely important for removing a debilitating stigma that created a second-class citizenship, unable to seek assistance in very essential and necessary ways. In the context of this work, it is truly important in creating a sense of courage and agency amongst these and other migrants, who now may feel more secure in acknowledging the need for counselling or supportive type groups, as will be highlighted in some of the service providing organizations.

The juxtaposition of this movement towards progress at the municipal level with the federal level which is clearly and with great dedication moving towards an economic utility approach of utilizing migrants for the economic gain of Canada, creates an interesting paradox in terms of the current political climate of immigration. Non-status peoples are thus assumed to be failures of the immigration system which prefers highly qualified and skilled migrants, unable to meet the demands, or failures in the process of attempting to do so. The blame in this complex political web is placed upon the individual migrant for not meeting the requirements, or being assumed to have ulterior motives for not attempting legal transparency from the start (Focus Online, 2013). It is also important to notice the stark decline in acceptances into the GTA in the 
Humanitarian Category (Figure 1), as a reflection of this paradox exemplified in migratory patterns. This climate feeds into the "contestant enmity" environment of the receiving society, in this case Toronto, where separation keeps a required distance, as these non-status people threaten to penetrate the Toronto community. What is perceived as strange in juxtaposition to the familiarity of "true" immigrants - those who have successfully navigated the system with their merit and transparency - is deemed unwanted and either consciously through policy, or subconsciously at a more personal level of social interaction, made to feel unwelcome or inherently separate from the city in which they live (Schmidt, 2013; Cohen, 2006).

This political climate sets the stage for the three service providers which will be analyzed in section five. Working from this foundation of the current Canadian and Torontonian context of informal non-status categories and small municipal steps in the direction towards equal access and the recognition of non-status people's needs - specifically mental health - the picture of the German and Aachener context will now be painted to allow for a clear comparison and contrast between the two nations and cities, followed by the specific service provider analyses. 


\section{Section 4: German and Aachener Context}

\section{Demographics \& Background:}

Aachen, Germany is situated on the boarders of the Netherlands and Belgium, making it the Western most city in Germany. Sitting roughly one hour south of its more internationally recognized neighbour Cologne, Aachen benefits from its accessible location and position within the State (equivalent to the Canadian Province and Territory geography), of NordrheinWestfalen. The demographic make-up and social composition of Aachen differs considerably from that of Toronto, as first and foremost, it has a much smaller population of 248, 137 in 2012 (Stadt Aachen, 2012), and would not necessarily come to mind as a main gateway for immigration, or even being an international, cosmopolitan city like that of Berlin or Frankfurt. However, the unique component of Aachen is that it is highly recognized for its educational institutions, such as RWTH Aachen University, and is extremely attractive to international students and academics, which make up a large portion of the city's migration flow (Föbker \& Temme, 2013). This differs from Toronto which sees large immigration flows mainly business and employment related, as newcomers to Canada opt for larger cities with more perceived opportunities (Statistics Canada, 2006). Aachen sees the majority of its foreigners being somehow intrinsically tied to RWTH (Föbker \& Temme, 2013). Regardless of the migration motives of the majority of immigrants within Aachen's borders, the fact remains that 34, 440 or $14 \%$ of its total population are foreigners (Stadt Aachen, 2012). This is a fairly impressive statistic for a city that is not considered to be a metropolitan hub of business or employment opportunity. The city attempts to set plans and goals for the future, in terms of developing an internationally attractive and welcoming city for international highly qualified migrants and

professionals from abroad (Föbker \& Temme, 2013). This initiative is further supported by 
federal government bodies, which are financially sponsoring the undertaking of large research projects aimed at understanding what attracts highly qualified migrants to Germany specifically the Nordrhein-Westfalen Region (NRW) - and how better to position itself as an internationally attractive country, with a welcoming culture that nurtures these new professional relationships. The goal being that these desirable migrants will feel a sense of welcoming community that will foster feelings of attachment and "home", thus enticing them to stay more permanently (Föbker \& Temme, 2013). This trend towards highlighting the benefits of economic migration is not central only to Aachen, but rather to the entire territory of NRW, and Germany as a whole. Until 2011, Germany had not conducted a national census since 1987. Demographic figures and population characteristics relied mainly on guesswork and exploratory figures based upon the earlier census findings (Birg, 2010). However May of 2013 saw the first release of the initial statistics and demographic findings of the 2011 census (Migration und Bevölkerung, 2013). What was discovered in Germany as a nation, was a total population of 80.2 million people, which is 1.5 million less than previously thought (Stätische Ämter des Bundes und Länder, 2013). Further to the point of incorrect assumption, the number of foreigners present in Germany was 1.1 million or $14.9 \%$ less than originally thought, with an actual total of 15 million or 19\% of people with a migration background (Stätische Ämter des Bundes und Länder, 2013). There is some debate around the validity of these figures, as German municipalities are also responsible for gathering population figures through the registration process. These municipally based figures do not appear to, according to some cities, correlate or match those reported in the official national census.

Official German classification of foreigners contains many categories and sub-categories, all of which appear vaguely similar. The main idea portrayed from this organization of 
terminologies, is that it is extremely difficult to be considered "German" while living in Germany. For example, the terminology of 'migration background', different than that of foreigner, according to the Federal Statistical Office of Germany (2012) refers to immigrants who have arrived in Germany after 1949 or a person with at least one parent who has migrated post-1949. Therefore this means that multiple generations after the initial migration would still continue to be classified as a person of migrant background living in Germany. These strict classifications of entry into the category of "full-German" are, in the opinion of the author, representations of the German mentality of belonging and reflective of the idea of citizenship being defined by one's ancestry and an imagined community which excludes immigrants (Bauder, 2011). Research in the area of demographics, future German trends and social composition support this notion, as Herwig Birg (2010) describes his concern regarding the falling birth rate of "Germans" due to his theory of more developed lands having lower birth rates among the host population. With a birth rate of 1.2 for "German" women, and a comparatively higher rate among immigrant women in Germany, Birg airs his concerns, which are highly contested as problematic and reflective of moral panic, that the composition of Germany is in danger of becoming less "German" and overrun with immigrants with higher birthrates from countries such as Turkey, Tunisia, Egypt and Morocco (Birg, 2010). His definition of immigrant appears to fall in line with that of the federal government, as he explains immigrants to be people without German nationality but living in Germany, or people with mothers who are not German - however this does not apply to Aussiedler, or German re-settlers who are assumed to intrinsically have German nationality through heritage and blood-lineage privilege. The 2011 statistics show that of this group considered to have migration backgrounds, $28 \%$ were born in Germany to foreign parents, $28 \%$ were foreigners born outside of Germany, 
$32 \%$ were Germans born in a foreign country, and $12 \%$ were foreigners born in Germany (Migration und Bevölkerung, 2013).

Nordrhein-Westfalen is the most populous land or territory in Germany with $17,845,000$ inhabitants. Of this total population, 4, 272, 000 have what the government would deem a migration background (Federal Statistical Office of Germany, 2012). In terms of population movements and migrations across the NRW and national borders, the territory had an average balance of movement of 17,324 for 2010, but was one of the few territories to report a negative net migration between State borders for the same year, of -10, 125 (Federal Statistical Office of Germany, 2012). What is evident from the census statistics, is that NRW is still an extremely populated region with flows of migrants and inhabitants consistently moving in and out of its borders. Researchers such as Herwig Birg (2010), Frank Kalter and Benjamin Schulz (2013) and Claus Richter (2013) have argued based on demographic figures and social assistance calculations, against the large migration flows, in belief that the majority of these migrants are not what the current government initiatives would consider highly qualified migrants.

\section{Migration Reality \& Anti-Immigration Sentiment:}

Resistance against increased migration and migration-friendly policies are common in Germany and NRW, and would inherently affect Aachen and its migration and recruitment scheme. Germany has consistently struggled with its identity as an immigrant receiving nation, as it attempts to move from a nation-state based history, to an innovative future that sees the successful integration of newcomers and communities alike (Süssmuth, 2009; Soysal, 2012). Pushes in migration legislation towards highly qualified migrants is echoed throughout research which claims that the qualifications and education levels of migrants differ greatly from that of 
native Germans, thus explaining the lack of success for newcomers in the German education system and employment market (Birg, 2010). Lower school attainment is tied intrinsically to lack of work success, which is then correlated to higher numbers of migrants as recipients of social assistance (Sozial Hilfe, 2013). Poverty risk assessments included in the 2011 census reveal that non-migrant populations in Germany are at risk of poverty at a rate of $11.7 \%$, compared to those with migrant backgrounds at 26.1\% (Federal Statistical Office of Germany, 2012). Unemployment rates among foreigners was reported at 2 times higher than that of nonforeigners, which many academics are still relating back to the 1973 conclusion of Germany's guest-worker program (Sozial Hilfe, 2013; Kalter \& Schultz, 2013; von Stritzky, 2009; Bauer et al., 2000). Once the program was halted as a result of the economic recession of the 1970's, family reunification initiatives were implemented as a way for workers already within Germany to bring their families to Germany to be with them. Anti-immigration extremists believe that many guest-workers exploited this right, as workers understood if they were to leave Germany they would not be able to return under any other visa scheme. Therefore, workers opted to claim their reunification rights bringing family members to Germany to start a life there as a united family unit - a movement which right-wing critics believe resulted in high numbers of uneducated or low achieving newcomers into Germany (Kalter \& Schulz, 2013, Birg, 2010). These fears highlight this time as being problematic in the educational composition of Germany, while not accounting for the ways in which immigrant groups were and are segregated into parallel societies throughout Germany, and specifically Berlin (Soysal, 1994; Birg, 2010; Winter, 2010; Angenendt, 2007; Eckardt, 2007) Birg (2010) states that parallel societies exist because newcomers orient themselves that way, aiming to develop ethnic communities. Claiming that immigrants cannot "identify without our history" (Birg, 2010, pg. 29), feeds into his fears that 
Germany is a magnet for fake migration incentives, and that young Germans will become the minority, questioning who, in the future, will need to integrate. Despite not being specifically focused on "tolerated" peoples, his argument proves to be more of a representation of fear mongering rather than sound academic work. The fact is that "tolerated" peoples are also not entitled to government funded integration courses, however Section 44, paragraph 4 of the Residence Act states that they may be permitted after a longer time, when vacancies are available (Bundesministerium der Justiz, 2012). Interestingly, lack of language acquisition is assumed to be from lack of interest or effort on the part of the migrant, and often intrinsically tied to lack of educational and employment achievements among immigrants in Germany (Wendland, 2011; Devoretz et al., 2002). Yet this policy indicates the ways in which "tolerated" people are simply unable to take part in this learning and socialization process.

Rates of unemployment and social assistance benefits of various kinds including the German equivalent to welfare benefits, entitled Hartz IV, are of the utmost importance to a variety of researchers aiming to prove that immigrants are simply migrating into the social welfare system (Birg, 2010). Germans with a migration experience were recipients of unemployment benefits at a rate of $42.4 \%$, whereas Germans without such an experience reported only 5.3\% (Federal Statistical Office of Germany, 2012). Such figures and vague and confusing terminology can be utilized to argue a variety of points regarding the neediness of newcomers, without taking into account any social or migratory factors that affect one's ability to be a self-sufficient income earner. Fears and anxieties as reported by Birg (2010) are echoed throughout other academic works, and political positions on the migration issue. Vietnam-born Phillip Rösler, Chairman of the Free Democratic Party -a classical liberal political party advocated recently for educated migrants, seeing them as a win for Germany (Migration und 
Bevölkerung, 2013). These sentiments are not reserved for only one side of the political spectrum, but rather supported by politician Hans-Peter Friedrich of the Christian Social Union, through his comments warning against "poverty migrants" and their misuse of the social benefits as well as their inclination towards welfare fraud (Migration und Bevölkerung, 2013; Focus Online, 2013).

In a migration climate as hostile and confusing as this, it is not difficult to find opponents to migration, utilizing this data to display the numbers of migrants dependent upon Hartz IV payments by nationality. These statistics show countries such as Iraq (64\%), Afghanistan (52\%) and Pakistan (47\%) and the share of foreigners of this background who are receiving these benefits (Bundesagentur für Arbeit, 2012). I would not argue that these statistics are false, however using them to discredit the validity and economic capabilities of these populations is unsound and unreliable research, as yet again, no background or transitory factors are taken into account in regards to the migration process of these groups that would justify why the dependence on social assistance may in fact be warranted. Regardless of reasoning - this climate of migration debate gives birth to the push towards the recruitment of what would be considered the ideal migrant for contemporary Germany - the productive economic migrant. With the constant bombardment of negative statistics such as those correlations drawn above, it is no surprise that in a recent 2013 poll reported through Focus Online, 28\% polled wanted to allow EU migration but only from specific countries, and $41 \%$ wanted restrictions placed on all EU countries (Focus Online, 2013). This is reflective of growing concerns and fears regarding the Roma population from Bulgaria and Romania - which migration expert Klaus J. Bade criticizes as being a hysterical reaction based on panic (Focus Online, 2013). This is also reflected in the March 2013 German veto against the admission of Bulgaria and Romania into the Schengen area 
(Migration und Belvölkerung, 2013). A joint project spearheaded by Frank Kalter and Benjamin Schulz, supported by the German government and EU funding bodies, stretches across the EU to discover how migrants' social and school relationships have fostered, and whether integration was successful or achieved (Kalter \& Schultz, 2013). Reporting foreign populations of $30 \%$ in kindergarten, and $25 \%$ in grade five, these researchers are aiming to find the reasons behind the increased levels of educational and employment difficulties for people with migrant backgrounds, and further hope to explore the effects of ethnic enclaves, specifically, whether they are a help or hindrance in the future job market (Kalter \& Schultz, 2013). These researchers touch upon the German notion of "Vitamin B", and the importance of having the right connections within German society to be successful socially and economically. This is important in terms of the recognition that it is not necessarily what you know, but who you know.

\section{Asylum Process: Legalities and Realities}

The migration climate in Germany is an example of identity formation of its own, as the nation struggles to find an identity which is an acceptable balance between fierce nationalism and being an immigrant receiving nation (Bauder, 2011; Winter, 2010). The debate as to what is necessary for Germany's success, as well as what is Germany's humanitarian responsibility is hotly contested and extremely public. From this point, looking at the logistics and legalities of the German asylum process and the categorization of "tolerated" will help to build a more clear understanding of the migration reality for this precarious population. The process of asylum application is very similar to that of Canada. Germany offers the right to asylum for reasons such as political, religious, ethnic, identity and "racial" persecution (Article 16) (Schuehrer et al., 2013). Similar to the Safe Third Country Agreement that Canada shares with the United States, Germany is partner to what is called Secure Third States, implying the same meaning - that 
countries surrounding Germany are considered to all be safe countries and therefore asylum applicants applying by land, air or ship would not be eligible technically to apply within Germany. This is part and parcel of the EU and Schengen Agreement (Schuehrer et al., 2013). Entry visas are needed from countries other than the EU, such as tourist or student visas therefore the assumption from the beginning of the process is that these applicants are bogus in some way, in that they specifically chose to seek refuge in Germany - a point which is often used in counterarguments which support Birg's (2010) assumption that Germany offers an easy transition into the social welfare system and because of this, serves as a target for immigration fraud. It is reported that when receiving advice about how to claim asylum in Germany, assistants recommend using a tourist or student visa to initially gain entry, and then apply for asylum once within Germany's borders (Schuehrer et al., 2013). This can also be problematic for asylum seekers who have applied for a Schengen Visa to enter the Schengen area, as this would require that the application for asylum be submitted to the embassy of the country which provided the visa (Schuehrer et al., 2013). When an eligible migrant seeking refuge makes it to Germany, they can ask at the border for asylum, where they would then be directed to the nearest institution for processing of the application. They can apply through the Foreigners Office or BAMF (Bundesamt für Migration und Flüchtlinge - the office for migration and refugees) (Schuehrer et al., 2013). The data shows that only about 65,000 applications for asylum were processed in 2012 (Migration und Bevölkerung, 2013). The main source countries reported for this period were Iraq, Afghanistan, Syria, Russia and Serbia (Migration und Bevölkerung, 2013). It is interesting here to note the correlation between the top source countries reported, and the top countries listed as recipients of social benefits in the previous section. One can assume that they are simply migrating into the system as expressed through Birg's (2010) work, or one can choose 
to look deeper into the human perspective of the situation, and see the correlation being a result of needing time to become settled, learn the language, and of course, deal with the mental and emotional stresses of migration under such difficult circumstances. It is important however, to note that this number of applications has increased $41 \%$ from the previous year, and contrasted with the 2006 figures of only 21, 029 applications, does indeed show an upward trend of increased asylum migration towards Germany (Schuehrer et al., 2013). The 2006 numbers were the lowest to be reported since 1983 and therefore may be a result of other factors such as legislative change (Süssmuth, 2009). Regardless, this assists in giving perspective as to the current panic around increased numbers and concerns about the ability to financially sustain the current aging German demographic and the influx of potentially lower earning newcomers (Birg, 2010).

The process of asylum determination can take years, with the possible negative results being; ignorable (applicant arrived through a deemed safe third state), obviously unfounded (applicant believed to have entered illegally with false information or forged evidence) and unfounded (reasons given not deemed sufficiently plausible, or not significant enough) (Schuehrer et al., 2013). The category of "tolerated" comes into play here, as an applicant who has received a negative outcome is obliged to depart, but cannot be deported at the current time as a result of legal or technical deportation obstacles, or the political climate in the country of origin, the status of "tolerated" will be given (Schuehrer et al., 2013). From the reported 65,000 applications in 2012, only 8,800 were accepted, with the majority for victims of war from Syria, Afghanistan and Iraq, with the rest given deportation orders (Migration und Bevölkerung, 2013). Of the assumed 56, 200 rejected claims, 8,400 were issued deportation bans, or what can be assumed, the title of "tolerated" (Migration und Bevölkerung, 2013). This title is a formal 
approach, similar to the "protected" of Canada's asylum system, yet much confusion in the German context is evident- specifically around the area of whether or not it is considered to be a residence permit. Technically the maximum period for toleration is six-months, but it can be extended if circumstances persist. Despite not having a formal residence permit, it is an allowance of residence as no other legal option is currently possible. Common legal deportation obstacles include the protection of marriage or family, and factual deportation obstacles would be circumstances such as a lack of passport, failure to find a country to accept a deportee or inability to travel as a result of illness or pregnancy (Schuehrer et al., 2013). These rights are protected in the Law of Residence, Article 60, paragraph 2 which states that persons cannot be deported to their home country provided that return is unreasonable caused by situations of; threat of torture, execution, violations of UNHCR or significant threat to life, freedom or physical state (Schuehrer et al., 2013). From the very definition of a "tolerated" person, it is clear that their situation - as the government also agrees - is that of trauma and fear, thus making this population extremely vulnerable to feelings of anxiety and depression. It is also not farfetched to believe that the title of toleration, in its very nature of instability and lack of clarity, can create an extreme and unique living situation. What adds to the precariousness of this situation is the fact that despite the initial six-month limitation on "tolerated" residence, 53,000 of the current 87,000 "tolerated" peoples in Germany have been living there for six years or more (Pro Asyl, 2013). Further legalities for this group include the initial granting of 'basic toleration' which forbids this group from working except for special circumstances. After a 2-4 year period and the successful completion of the labour market test, "tolerated" peoples may be granted working rights (Bundesministerium der Justiz, 2012). They are also not entitled to unemployment benefits or social assistance - but rather dependent upon specific legislation entitled the Asylum Seekers 
Benefit Act (Bundesministerium der Justiz, 2012). This act dictates the appropriate amount of monthly income to cover food, shared accommodation, heat, clothing, health and personal care and household goods (Bundesministerium der Justiz, 2012; Statische Bundesamt, 2013). “tolerated" peoples must wait 48 months to be eligible for regular social security benefits and health insurance. They are not eligible for Hartz IV (Bundesministerium der Justiz, 2012). The government of Germany provides statistics regarding the amount of those receiving the specified Asylum Seekers Benefit by territory, for the years of 2010 and 2011 - which show an increase during this period for NRW from 36,128 to 40,814 . This represents a $13 \%$ increase from the previous year, which is one of the highest of all 16 regions (Statisches Bundesamt, 2011). With asylum applications on the rise, as exemplified with a reported 30,000 applications in the first four months of 2013 (Migration und Bevölkerung, 2013), it is clear that the realities and human perspective of the situation need to be addressed at a deeper level, bringing clarity and awareness to the hardships and effects on the mental health and coping mechanisms of this increasing population.

\section{Mental Health Concerns:}

Groups advocating for the rights of asylum seekers, and "tolerated" peoples specifically, argue that this group face hardships and difficult times in Germany (Pro Asyl, 2013). Campaigns such as "Save Me", organized through a network of local level service organizations and larger organizations such as Pro Asyl, Caritas and Diakonie, argue for the 'Bleibrecht' or right to stay, for asylum seekers and "tolerated" peoples (Pro Asyl, 2013). Mental health arguments are brought in for the fight to gain understanding that the living situation of "tolerated" peoples is one of constant strain, and is vulnerable to unique hardships and dangers associated with such precariousness. Advocates argue that "tolerated" peoples are constantly threatened with potential 
deportation and thus, cannot shape their futures in Germany. It is difficult for this group to have healthy life perspectives, as they continue to be intrinsically tied not only to the nation, but to the states where they reside (Pro Asyl, 2013). This is due to the restrictions placed upon "tolerated" peoples geographically, as they are required to stay within the territory where toleration was granted. Any desire to move outside this territory requires a 'leave permit', until unrestricted right to work or attend school is granted (Bundesministerium der Justiz, 2012). This creates not only a social exclusion as articulated by contestant enmity, but rather a physical geographical space, binding "tolerated" peoples into an area, with freedom of movement resting in the hands of government officials. This physical entrapment can easily translate into mental and emotional confinement, adding to feelings of segregation, helplessness and loss of control of power over one's life. This is clearly in direct contradiction to the previously stated WHO definition of mental health which included a feeling of productivity and fruitfulness as being necessary to achieving a healthy mental state (Mckenzie et al., 2009). This is what Kirmayer et al., (2011) would categorize as the post-migration phase, which is associated with a sense of powerlessness that can provoke or aggravate depression and other mental health problems. Looking at the employment situation, it becomes a double-edged sword as this specific population is legally denied fruitful employment, with residence-status being consistently impermanent, yet are faced with backlash from a German migration perspective which assumes a negative outlook on migrants looking for social handouts. This creates another realm of imprisonment based on miscommunication and lack of clarity, as community members may not fully understand the employment restrictions placed upon "tolerated" peoples, and "tolerated" peoples themselves may have the desire to work productively, yet are again at the mercy of government which forbid them from doing so. With the requirement to wait two-four years to complete the labour market 
test that would allow a work permit to be granted, and the unknown date at which they may be permitted to enter into a government funded language and integration course, "tolerated" peoples are placed at a distinct disadvantage in terms of being able to feel a sense of belonging within the community (Bundesministerium der Justiz, 2012). Unemployment or underemployment, as well as difficulties with the new language are all highlighted by Kirmayer et al., (2011) as postmigration factors that affect mental health, with language proficiency often having a greater influence on specifically men's employment and subsequent mental health (Kirmayer et al., 2011). Both physical and social separation make it difficult at best, for "tolerated" peoples to be a part of the broader German community. Therefore it becomes more clear that the mental health and state of being are affected not only as a result of the initial traumatic migration narrative, but the difficult and obstacle-laden reception into the German cityscape. In terms of the city of Aachen specifically, the local newspaper wrote an article in 2011, which personally interviewed an Iraqi asylum seeker, as a part of raising awareness of the "Save Me" campaign (Sillius, 2011). In her reporting, Sarah Sillius discussed with Shilan F., her traumatic experience, and persistant pain at her separation from her father who is still in Iraq (Sillius, 2011). She highlights the emotional stress and the need for community involvement to overcome feelings of isolation and sadness. Importantly, she touches upon Aachen's role in the receiving of refugees, by stating that out of 2,501 Iraqi refugees, 30 were received in Aachen (Sillius, 2011). This article, along with the "Save Me" campaign prove to be relevant and contemporary ways in which the community as well as Aachen specifically, are working to attempt to create awareness of how it feels to be a refugee - which is a shift away from the more common statistical and negative financial reporting on the issue. 
It also marks an important shift to the discussion of mental well-being, and the need for community involvement and acceptance as a tool for good health, which will be touched upon in a following section which looks more specifically at the community and service organization initiatives present in Aachen.

\section{Current Political Climate:}

As previously outlined in the discussion on the migration debate in Germany, the current political climate is also one of identity formation, and development - in the quest to find a balance which benefits Germany economically, appeasing all important players, while also meeting the humanitarian obligations to which it has pledged its support. It is important to touch upon the Süssmuth report in this discussion, as it highlighted the main immigration policy developments since 2000, as well as formulated important recommendations for the future of Germany’s immigration system (Süssmuth, 2009). The report and Süssmuth's following updated 2009 presentation for the Transatlantic Council on Migration importantly noted the continued German identity debate, and the slow emergency since 2004, of Germany accepting itself as an immigration nation, while still placing restrictions upon that identity (Süssmuth, 2009). Finally confessing that it is culturally, ethnically and linguistically diverse, Germany is moving towards the attraction of skilled migrants and improving the relationships between various community and ethnic groups (Süssmuth, 2009). This is consistent with Soysal's analysis of the current European perspectives on citizenship and immigration, as she states that lower skilled workers are rendered invisible in this policy maneuver, and not valued as members of the competitive economy. Further, she argues that, "the polarization of labour markets between insiders and outsiders is regarded as a syndrome of the post-industrialized, globalized economies" (Soysal, 2012, pg. 7). Germany according to Soysal (2012), focuses citizenship on being inherently tied to 
work, labour market policies and vocational training. Süssmuth's recommendations follow this ideology by taking a stance towards an increased effort on the part of "Germans" to create acceptance among immigrants, while still advocating strongly for Germany's "competition for international talent" (Süssmuth, 2009, pg. 6) as well as for Germany's future ability to, "successfully fish from the international talent pool” (Süssmuth, 2009, pg. 7). This employment and qualification focused model reflects that highlighted by Soysal (2012) as she explains that the individual migrant is viewed as responsible for their capacities and efforts to take part productively in the institutions offered in the system. Furthermore, on the issue of productive community engagement, she states that, "being productive, creative and active defines a higher form of life" (Soysal, 2012, pg. 12). In the German climate, migrants are viewed as being responsible for their own success, with the greatest importance placed upon academic and employment achievements. Süssmuth's policy recommendations are reflective of this German mentality, but still provides hope in terms of future possibilities, as she does indeed highlight a helpful "two-way street approach" where all community members take part, and further utilizes vocabulary such as "trust" in terms of the relationships that need to be built between policy makers and minority groups (Süssmuth, 2009). She also echoes the findings by Bhuyan (2011) by raising the importance of community relations and positive interventions at the community level (Süssmuth, 2009). Although Süssmuth acknowledges the lower achievement levels and lower socioeconomic realities of ethnic and minority groups within Germany, rather than taking the individual blame approach as many of the previously mentioned researchers have done, Süssmuth chooses to argue that it is the responsibility of state-level governments and an overhaul of the rigid pathways/structures to make change (Süssmuth, 2009). 
Focusing more municipally, the City of Aachen, through the 2006 published Integration Plan, acknowledges the difficulties newcomers in the city face, and highlight seven areas of activity in hopes of creating a stronger network of service providers for more accessible services (Stadt Aachen, 2006). The first four target areas that were prioritized as being of the utmost importance were; Counseling \& Support/Psychosocial Counselling \& Health, Language skills, Education, and Employment (Stadt Aachen, 2006). Interestingly the City of Aachen highlighted not only the necessity for supportive and accessible mental health care, but also prioritized it as being the number one area of concern and focus in the entire integration plan. The plan highlights the services available in the area of psychosocial counselling and supportive health, and creates a network between organizations, where goals and areas of achievement are highlighted and worked towards amongst all service providers. The integration plan outlines that the service providers in this network, working within this specific area, should work from a foundation of intercultural awareness to provide better service and counselling provision, with socially inclusive supports that allow the individual to participate fully in all social areas. Full participation is mentioned by the City of Aachen as being important for independent living (Stadt Aachen, 2006). This definition is reminiscent of the full participation mentioned by the WHO as a requirement for good mental health. Furthermore in the area of mental health care and supportive counselling services, the City of Aachen suggests a "Migrants for Migrants" approach, where more culturally representative health care providers would be available, in order to meet the specific needs of migrants, as well as to provide an inherent cultural understanding that may be lacking with a native-born German provider (Stadt Aachen, 2006). As well it may assist in breaking through cultural stigmas relating to seeking service. This is an example of the political climate at the municipal level, which is focusing its integration policy in the specific 
area of mental health care provision. It is important because it not only acknowledges the need and importance of these services, but because it places them above areas such as education and employment - which are economic utility tools of governments aimed at the utilization of migrant's abilities - to meet their own national economic needs (Bauder, 2011). 


\section{Section 5: Service Provider Analysis}

The service providers in each city were selected based on geographic location - being that they are fairly spread out rather than concentrated in one region of either city. All agencies have various specializations and services offered, yet all focusing on newcomers and refugees. The aim was to get a broad overview and understanding of how variously mandated organizations are meeting the needs of non-status or "tolerated" peoples, regardless of whether this group was their target demographic or not. The agencies were also chosen based on exhibiting different philosophies, such as a religious base, or being more corporately affiliated. Overall, agencies that were chosen and will be discussed, span over a wide range of target populations, funding bodies, philosophies, and mandates.

\section{Toronto:}

As previously shown, mental health services do not fall under a priority of funding bodies. OHIP or government health services cannot officially offer any other than what one might consider traditional mental health services such as appointments with psychiatrists, psychologists or registered therapists - all of which would be OHIP covered and therefore a deterrent to any migrant not eligible under that program (such as precarious or non-status migrants). This becomes more problematic as Bill C-31 - a bill targeting refugee claimants rather than non-status peoples - would impose a prohibition for refugees to obtain permanent resident status within their first five years of landing and thus be denied access to government funding health care aka. OHIP (No One is Illegal, 2012). Local service providers have thus attempted to fill this gap by offering alternative services. 
The Canadian Centre for Victims of Torture (CCVT) is an example of an organization that specifically targets a group of people, often refugees, and creates a supportive framework to address their individual needs. Examples include supportive counselling to assist with healing trauma, and an emphasis on the development of trust between service users and staff (CCVT, 2013). Through the use of mutual support groups for men, women, youth and children, this organization is able to address the unique needs of this group as well creating an environment that in its essence, acts as its own brand of mental health service without being labelled as such, as formal terminology such as 'mentally ill' can be culturally branding (Fenta et al., 2006). CCVT utilizes a coordinated effort of professionals such as doctors, lawyers and social workers, as well as a medical network - to meet the needs of service users who may be stigmatized from seeking assistance from a daunting and exclusionary provincial body (CCVT, 2013). This falls in line with current literature which suggests that many refugees or vulnerable migrants may be fearful of formal healthcare, and find it stigmatizing both personally and amongst family networks (Fenta et al., 2006). Mental illnesses and disorders are highly stigmatized in many countries, and therefore those suffering with symptoms may be very reluctant to attribute these symptoms to a mental disorder. This is often a reflection of the fact that mental health diagnoses are intrinsically tied not only to the individual, but to their siblings and other family members (Kirmayer et al., 2011). This organization works within an important niche of trauma counselling as well, as refugees often have traumatic pre-migration experiences that create un-met needs post-arrival (Simich, 2010). Therefore with this example one can see how the semantics of mental health discourse and labelling are important when working with a population that is often fearful of stigma or distrusting of formal approaches or family shame. 
Moving out of the downtown core to the suburban region of Mississauga, my next example is the Newcomer Centre of Peel (NCP). This is an organization that truly attempts to do it all - from employment readiness, to language instruction, to a brief mention of trauma support counselling (NCP, 2013). The discouraging issue with this provider is that it makes the all too familiar mistake of grouping trauma counselling in and amongst employment and career counselling - thus immediately showing the lack of specific and individual attention that these types of supports require. When asked during a speech given at Ryerson University, April $9^{\text {th }}$, 2013, the Executive Director of the NCP, Effatt Ghassemi acknowledged that NCP do not actually have specific trauma counselling, and appeared confused regarding its inclusion in the recent brochure. She did state that in her annual bid for funding, she includes a proposed mental health/crisis intervention worker, but is consistently denied (Ghassemi, 2013). With a reported number of 1,703 settlement clients for the year 2011-2012, it is evident that it is a fairly busy and growing service organization (Ghassemi, 2013). The majority of promotion for this site is done through web resources or a written pamphlet. This is also problematic in that research has shown that literacy, specifically health literacy levels, are low in the first few years of settlement (Simich, 2010). Further, with $32 \%$ of female and $24 \%$ of male newcomer respondents in Simich's 2010 study, highlighting extreme difficulty with printed materials, it is no surprise that written information alone is not enough to promote good health practices, or that many authors argue for a more community-based or verbal approach to the promotion of available mental health services (Simich, 2010; Hansson et al., 2010). The fact that NCP is largely funded by the federal government may have something to do with the emphasis on employment and language training in an effort to create economically integrated people who are able to contribute and give back to the nation that allowed them to immigrate. Regardless of motive, this is a prime example 
of the ways in which often times, mental health counselling is not differentiated from other forms of counselling, or the way it is strategically aligned with other purposes or motives, such as in terms of producing tangible results for funders showing success of employment readiness or language programs. Unfortunately despite claiming a personal interest in mental health and depression among newcomers and refugees, Effat Ghassemi is unable to steer the goals of the NCP away from being largely employment focused, to address these serious needs (Ghassemi, 2013). The NCP lacks focus in its program administration and service provision as a result of previous addressed structural issues. Serving a large population in a busy suburban area creates the opportunity to achieve more than what is fiscally mandated, yet up until this point, it has failed to realize this potential.

A final example of the methods with which Toronto's service providers are attempting to address the mental health or counselling needs of all newcomers, is Becoming Neighbours Ministry located in Scarborough, a suburban area within the city boundaries of Toronto. Operating from a Catholic foundation, this organization aims to work with all immigrants, specifically refugees, regardless of faith or origin (Becoming Neighbours, 2013). It exemplifies another way in which mental health services are not explicitly stated in any online or printed promotional material, yet the goals are achieved nonetheless through a multitude of groups such as women's circles and language groups, which aim to provide emotional support and focus on the internal well-being of newcomers in a turbulent and isolating transition. Becoming Neighbours is a prime example of the strategic ways in which service providing organizations are utilizing a community level supportive approach to address depression, anxiety and coping difficulties without necessarily using a formal medical approach. This is often achieved through various group-based meetings, and partnerships among service users to create relationships and 
work on goals such as English language acquisition (Becoming Neighbours, 2013). With their work focusing most frequently on refugee populations within the city, and their religious foundation that focuses upon the individual rather than official documents or status, Becoming Neighbours is in a perfectly strategic position to provide services to non-status peoples through what is essentially a 'don't ask, don't tell' policy. Furthermore, by specifically highlighting their goal of assisting with the isolation and adaptation of their service users, Becoming Neighbours enforces an alternative approach to mental health which many authors would argue is the ideal community level and culturally based programming needed (Simich, 2010; McKenzie et al., 2009; Fenta et al., 2006; Khanlou, 2010).

\section{Aachen:}

Although being a legally recognized category and sub-category of residence, "tolerated" peoples in Germany are not entitled to full health care benefits (Statistche Bundesamt, 2013; Bundesministerium der Justiz, 2012). Health services offered are generally basic or emergency care focused, or with duty of care falling upon municipally focused health departments which provide dental and medical care for children and youth (Bundesministerium der Justiz, 2012). Social and health services are oftentimes inadvertently billed by care providers to the government out of confusion, and therefore covered by public funds (Bundesministerium der Justiz, 2012) however this is not reflective of the legal processes in place regarding the organization of health benefits for "tolerated" persons. It serves more as an example of the ways in which community players at all levels can be confused as to the legalities of the "tolerated" category. Mental health care provision, much like in the Toronto circumstance, is overlooked in favour of more medical and formal ideologies of good health and health care provision. The confusion regarding the category of toleration, as well as the entitlements and restrictions that 
come along with it such as which areas of health care are covered under their basic plan or the validity or expiration of their temporary residence permits, can create inconsistencies in care, as well as confusion among service users themselves, as to what may be available to them, and what is reserved for German citizens or nationals. Therefore the role of the local level service organizations in Aachen is to play a central role not only in the provision of service, but also in bringing awareness to "tolerated" peoples about their entitlements to access services.

Aachener Engel, literally meaning Aachen's Angel, is a located just on the outskirts of the central city core, in a fairly busy and populated area. The role of the organization is expansive and stretched across many service areas including working with sick children and underprivileged peoples, victims of discrimination and bullying, as well as newcomers and immigrants within Aachen (Aachener Engel, 2013). In terms of working specifically with "tolerated" people, a Youth Worker stated that they are welcome to attend events hosted by the organization, however the lack of proper documentation such as a personal identity card may prove problematic as ID's are checked during outings and events hosted by the organization. The focus of the programs targeting newcomers takes on an integration perspective, literally being entitled, "Integration Help", focusing on areas such as German language assistance, cultural understanding, family problems and racial prejudices (Aachener Engel, 2013). This coincides in a fairly linear way with the goals of Germany's push for integrative measures, as well as Aachen's city integration plan - both of which highlight the importance of German language, as well as inherently placing the bulk of the work upon the individual migrant (Stadt Aachen, 2006; Süssmuth, 2009). Aachener Engel reported not having many "tolerated" service users, but rather people undergoing the asylum process, which the Youth Worker stated often just appreciated talking to someone about their issues or the complexities of the administrative procedure 
involved with asylum application. Thus, Aachener Engel does assist by accompanying newcomers to the City of Aachen offices or Foreigner's Office to connect them to the necessary services. Looking specifically upon integrative programming and room for mental health assistance, Aachener Engel prefers to refer all mental health needs to a neighbouring Psychiatrist's office, as they are seen to be the expert (Aachener Engel, 2013). This is representative of a formal mental health approach that acknowledges mental illness as being something exclusively handled by medical professionals - which is problematic for a "tolerated" population without legal permission to work or medical benefits covering such visits. Specifically, the fact that psychiatrists are able to prescribe medication, which thus reflects the views that mental health is best handled through medical intervention addressing more biological determinants of mental illness without acknowledgement of other more holistic or therapeutic approaches beneficial in treating situational depression. The methods most used by this organization focus on youth group activities such as sports and movie events, all of which are funded by the organization, on behalf of various private and corporate sponsors throughout the city. Despite the name being reminiscent of a religious organization, no specific mention in any public material was made of any religious affiliation or sponsorship.

Café Zuflucht, or Sanctuary Café is a small organization also located slightly on the outskirts of the main city core in Aachen. Its focus is upon refugees and asylum seekers, with staff also specializing in unaccompanied minors. The most important mandate of the organization is to assist with everything paperwork and administratively related, which sometimes provides the opportunity to advocate on the behalf of the service user (Café Zuflucht, 2012). With over twenty years of service, Café Zuflucht is well known among migrant networks, with the majority of new service users being made aware of services through these networks, 
many of whom previously sought service from the organization (Café Zuflucht, 2012). Taking the form of a small café with tables, couches and free coffee, tea and snacks, the environment appears to enable a feeling of welcome that fosters socialization amongst service users themselves. 2012 saw 701 service users seeking advice, with 421 (60\%) men and 280 (40\%) women (Café Zuflucht, 2012). Of the total service users, 96 were of the "tolerated" category, and 288 had other forms of temporary residence permits (Café Zuflucht, 2012). The main source countries seeking services from this organization were the Democratic Republic of Congo (152 or 22\%), Nigeria (79 or 11\%) and Afghanistan (77 or 11\%) (Café Zuflucht, 2012). Official publications from Café Zuflucht state that the majority of service users are indeed coming from countries of war or experiences of trauma. Furthermore the organization sees large numbers of unaccompanied minors, which they state has increased since 2010 to a figure of 119 in 2012 (Café Zuflucht, 2012). Maintaining relatively good relations with the Foreigner's Office in Aachen, Café Zuflucht is more capable of advocating for clients as well as making sure that they too are knowledgeable in all official practices relating to asylum in Aachen (Café Zuflucht, 2012). "Open" consultation times occur between $10 \mathrm{am}$ and $1 \mathrm{pm}$ daily, with longer or more complicated tasks requiring private appointments of a more on-on-one nature (Café Zuflucht, 2012). An important point in regards to working with this precarious population, is the free access to service for all service users, as Café Zuflucht is funded by the City of Aachen, the territory of Nordrhein-Westfalen, the EU fund for refugees as well as corporate and private sponsors (Café Zuflucht, 2012). With the focus of this organization being mainly on administrative procedures and providing advice on the legalities of the asylum process, mental health concerns are referred to another local service organization that deals specifically with 
refugee and asylum seeker's mental health issues. That organization is entitled Pädagogisches Zentrum Aachen.

Pädagogisches Zentrum Aachen (PAZ), or Educational Centre of Aachen, is a social service agency that too, is geographically located within a ten-minute walk from the city centre. It is well known amongst social service networks for its specialization in mental health issues, and therapeutic methods. However, Pädagogisches Zentrum Aachen focuses not just solely upon immigrants, refugees or asylum seekers, but rather advocates welcome for all groups including youth and adult immigrants, bi-nationals or Germans (Pädagogisches Zentrum Aachen, 2013). Starting as an unemployment initiative in 1983, PAZ began to recognize the other needs of the inhabitants of Aachen, as well interestingly, those in the closely neighbouring nations of the Netherlands and Belgium (Pädagogisches Zentrum Aachen, 2013). Currently, PAZ works closely with the "Gleichbehandlungsbüro" in Aachen, which is an office dealing specifically with discrimination and equality (GBB Aachen, 2013). PAZ today has programming that focuses on four main areas; Psychosocial Therapy for Refugees, Integration for Immigrants and their Families, Intercultural Workshops and Full-Day Schools for children (Pädagogisches Zentrum Aachen, 2013). All program areas work around the needs of newcomers, integration, discrimination and creating awareness and opportunities for these populations. Most importantly, PAZ sees integration as a community process, where all members either with or without an immigration story should work together in solidarity (Pädagogisches Zentrum Aachen, 2013). Much of the efforts of PAZ revolve around families and children, as they are seen as the middlepoint for achieving success in their target areas, with focus on social competency and relationship building. Informational brochures highlight staff as being an intercultural and 
qualified team aimed at tackling racism through these intercultural programs (Pädagogisches Zentrum Aachen, 2013).

The Psychosocial Centre for Refugees, part of PAZ represents an important mental health service for the "tolerated" peoples of Aachen. Conducted in the main building, the focus here is on counselling and therapy of various kinds. The available forms of counselling include; psychosocial, health, trauma and systemic counselling. Therapies include child and youth therapy where parents are invited to accompany, or art therapy conducted in either an individual or group setting (Pädagogisches Zentrum Aachen, 2013). The aims of all counselling and therapeutic methodologies is to help develop new perspectives and hope with this group (refugees or "tolerated" peoples), to help them to shape and self-create a better future. This is reflective of the criticisms raised by Pro Asyl and those involved in the "Save Me" campaign, who argued that the constant threat of deportation takes away one's ability to envision a possible future or have life perspective (Pro Asyl, 2013). PAZ argues that psychosocial counselling is fundamental, as it provides refugees with the opportunity to discuss their refugee story and actual life situation as a narrative upon which to creatively build their future ideas and goals (Pädagogisches Zentrum Aachen, 2013). At the same time, PAZ are interested in the economic, social, cultural and political conditions that create the refugee situations for their service users, which assists in creating understanding of the factors and stressors affecting this group, as well as providing a platform for the agency to advocate for them if needed (Pädagogisches Zentrum Aachen, 2013). Services available at PAZ are also free of charge to users, with funding provided by the City of Aachen, Nordrhein-Westfalen's office for Refugees and Employment as well as the EU's Funds for Refugees (Pädagogisches Zentrum Aachen, 2013). 


\section{Similarities and Differences in Service Delivery:}

The most notable and obvious difference in service delivery between Toronto and Aachen is the legalities that create the framework for providing service. With toleration being a legally recognized category, organizations may feel less fear offering services as well as may be more thoroughly informed as to what services and assistance "tolerated" peoples are entitled to. Whereas in the Canadian context, non-status peoples - despite the progress of Sanctuary City for Toronto - are still considered to be illegal migrants without many rights or freedoms. Therefore service users in Toronto may be either hesitant to provide full-service, or simply unaware as to what they can offer to this group, without endangering non-status peoples with potential deportation or trouble with the state. All three organizations in the Toronto context - Canadian Centre for Victims of Torture, the Newcomer Centre of Peel and Becoming Neighbours - do not explicitly state information or statistics in official brochures or annual reports regarding nonstatus peoples, or programming that is specifically targeted to this group. Building upon this point, only the Newcomer Centre of Peel highlighted mental health through the program of Trauma Counselling - yet even that was undermined by the lack of qualified staff to provide the service, or the awareness of the service provisions and mandate by the Executive Director herself (Ghassemi, 2013). All of which serve as indicators that the mental health needs of newcomers, refugees and non-status peoples is not on the agenda for service organizations within the city and especially not on the radar for government bodies.

Aachen on the other hand, thanks to the legal recognition of "tolerated" peoples and the provision of access to care through the various policies and legislation regarding this group, are able to access services in a way that non-status peoples in Toronto cannot. All service providers seemed aware of the "tolerated" population living within Aachen, and all with the exception of 
Aachener Engel seemed extremely knowledgable regarding their entitlements and needs as service providing organizations. As an observation, despite being a separate category than that of refugee or asylum seeker applicant, "tolerated" peoples appeared to not be treated much differently in terms of access to service. None of the three German organizations alluded to denying service - other than Aachener Engel being slightly more strict with requiring identification, which would only disadvantage those awaiting their toleration identification or temporary residence documents - therefore showing services in Aachen to be fairly aware of the demographics of the community they serve. The overall populations as well as immigrant flow rates differ fairly greatly between Toronto and Aachen, thus placing more pressure perhaps on Toronto service providing organizations who may feel overwhelmed with large numbers of service users of all immigration backgrounds and methods, thus not allowing sufficient time to become thoroughly knowledgeable in the needs and legalities of non-status peoples.

Another important difference between the organizations are the funding sources and in turn, the mandate that is formed based upon the expectations of these sources. Becoming Neighbours receives the majority of its funding from religious based institutions and religiously inclined private donors (Becoming Neighbours, 2013). This gears their services towards Christian-based counselling practices and thus, the informal mental health methodologies of group work and community bonding. No emphasis appears to be placed upon reaching integration goals, but rather providing strength and assistance with mutual language partnerships amongst newcomers (Becoming Neighbours, 2013). NCP on the other hand receives much funding from the government, including Citizenship and Immigration Canada, thus shaping their mandate to be very much employment focused. Therefore one can see that their programming overlooks mental health - both formally and informally - by opting for employment readiness 
programs, technology assistance programs, and state regulated language training and Business English courses (NCP, 2013). By adhering to national trends of economic utility of migrants, and reaping the benefits from newcomers in an international competitive global market, NCP fails to address or meet the needs of traumatized peoples. The CCVT adequately addresses the mental health needs through specific mental health counselling programs and crisis intervention methods (CCVT, 2013). Also receiving funding from governmental bodies such as Citizenship and Immigration Canada and the City of Toronto, CCVT is uniquely located as a specialist in trauma and refugee issues, and therefore is able to bypass an emphasis on employment readiness or productivity based programming. One can argue that this is an example of the way the City of Toronto chooses to classify service organizations, offering services to those deemed in need (recognized refugees), rather than acknowledging that migrants of all kinds, or non-status peoples accessing other services, may also be in need of mental health support. By choosing to focus mental health funding for mental health specific organizations, the City of Toronto is missing opportunities to meet the needs of precarious migrants who are seeking services elsewhere, or who may be afraid to access services in a centre associated with the stigma of being mentally ill.

Funding issues within Aachen are slightly different, as Café Zuflucht and PAZ are funded through various refugee funding bodies and government programs, and Aachener Engel relies upon private and corporate donations. Interestingly, the organization that relies on corporate support provides the least amount of mental health support, whereas the two government supported organizations work heavily in the area. This is slightly opposite to the case of Toronto, where organizations appear strongly mandated by government expectations, and Becoming Neighbours which relies on private support is able to take a more relaxed and mutual learning 
approach to working with refugees or non-status peoples. Overall services in Aachen are strongly supported by the city and tertiary funding bodies, with the emphasis being on refugees. This specified funding allows organizations to work more specifically with the needs of refugees, while networking with other service organizations that can provide more specialized care.

Methods of delivering mental health services differ among nations and service users at the municipal level. As demonstrated in previous sections, mental health care appears to take either a formal medical approach, a formal counselling or therapeutic approach, or an informal supportive approach - often without being specifically intended to do so. An example of formal medical approaches are that of Aachener Engel which chooses to refer psychiatric or psychological services to a formal medical professional rather than to PAZ or other informal group settings. Examples of a formal counselling or therapeutic approach are illustrated by Pädagogisches Zentrum Aachen, Canadian Centre for Victims of Torture, and the Newcomer Centre of Peel - with PAZ achieving their goals with success, CCVT providing an integrated approach, and NCP failing to actually provide a mental health worker. PAZ exemplifies an organized and formal set-up to the provision of mental health services on both an individual and group basis, in a session-based format, or a more holistic therapeutic method involving art expression. CCVT combines networks of medical professionals, with trained staff qualified in crisis intervention along with group work which emphasizes the sharing of migration narratives (CCVT, 2013). NCP attempts to follow suit by technically acknowledging the need and possibility of providing a mental health worker, but due to funding demands fails to actually do so. The final form of mental health provision takes the form of an informal approach, as displayed through Becoming Neighbour's and Café Zuflucht's emphasis on community and equality among service users and staff. Both organizations do not explicitly report offering 
mental health, but the solidarity and relationships formed through group work, and the informal and welcoming café setting provide opportunities for "tolerated" or non-status peoples to network with others in similar circumstances, overcome stigmas and gain social contacts, as well as engage in informal counselling opportunities through communication and sharing. 


\section{Section 6: Moving Forward to Better Service Delivery}

\section{Recommendations - What can Municipalities learn from each other?}

One can argue that what is displayed through the informal approach of Becoming Neighbours and Café Zuflucht is a suitable strategy for service providing organizations to offer mental health services without needing funding specifically for this target. It is evident that welcoming cultures - not just that pushed by national government bodies for highly qualified migrants - are effective ways of creating safe spaces and feelings of belonging during difficult transitions for vulnerable peoples. As previously discussed, the geographic and social isolation that "tolerated" or non-status peoples face in their migration experience and relocation into Toronto or Aachen, can be potentially combatted by opening spaces and opportunities for welcome within social service agencies such as exemplified above. As Bhuyan (2011) argues, devolutionary trends in social policy have privatized and decentralized the delivery of social services, therefore social services and NGO's are able to position themselves as important instruments for non-status peoples. Therefore government mandates and specific policies do not need to necessarily guide services, but rather the organizations need to create their own opportunities by positioning themselves in such a way as to meet the needs of their communities. The exercising of discretionary powers in daily interactions with immigrants provides social service providers with the tangible opportunities to advance the human rights of individuals, regardless of their status (Bhuyan, 2011). In this context, access to supportive mental health services is argued to be a human right for non-status and "tolerated" peoples. Both cities appear to be doing this in some capacity. However from the findings of the service provider's analyzed for this work - it appears as if Toronto organizations are adhering slightly more rigidly to their specified mandate, without acknowledging or acting upon the opportunities for growth, advocacy 
and informal mental health care. Further to this point, organizations do not appear to be fully embracing the reality that mental health is a rampant problem among non-status or "tolerated" peoples, which may add to challenges relating to ethnic stigmas surrounding the notion as precarious peoples would be left with the only option of approaching more formal avenues for mental health support (Simich, 2010). Sanctuary City provides an opportunity in the Torontonian context, for service providers to communicate and network more amongst themselves regarding services available to non-status peoples, as well as looking for ways to address mental health issues, feelings of anxiety, depression, isolation and fear that are not reliant upon a formal medical process. Toronto providers can learn from Aachen, the importance of informing staff and employees of the legalities and administrative processes associated with non-status and asylum applications, to better provide opportunities for assistance and advocacy, as exemplified by Café Zuflucht and their alliances with other community organizations as well as city officials. Although potentially tricky due to the illegal status of non-status peoples, and thus the duty to report to CIC still technically in effect for service providers (Keung, 2013), the importance of finding informal methods of meeting these needs is pressing in order to the benefit of all parties involved.

What Aachen can learn from service provision in Toronto, is the way in which the city has risen up through examples such as Sanctuary City, to show support for this vulnerable community, and to stand in solidarity behind them. Furthermore, by addressing and acknowledging that this population faces specific hardships unique to other categories of migration, Aachen can do the same in pledging support to "tolerated" peoples within its municipality. Despite having relatively effective and informed services, Aachen is extremely focused upon the recruitment of foreign academics and international students that will improve 
the image of the city. Aachen's migration pattern displays favouritism for highly qualified academics and international students. This focus on gain for the city, and international recognition on a global academic stage through RWTH's allure, leaves "tolerated" peoples far behind in terms of being made to feel valuable members in the city. In fact, the exceptional amount of positive attention paid to highly qualified and sought after migrants, works negatively towards "tolerated" peoples, as it serves as a reminder that they do not fit into the image of the idealized city. Furthermore, it serves as an isolating practice, as "tolerated" people are not able to attend educational institutions or receive government educational assistance (BAföG) until after a longer, specified time period (Bundesministerium der Justiz, 2012). This is further supported by the experiences of asylum seekers, such as a young Afghani asylum seeker quoted in a prominent German newspaper, Frankfurter Allgemeine as saying that he "felt like a ghost [in Germany]" (Schmidt, 2013). These isolating experiences are often reported in personal accounts of asylum or toleration in Germany (Sillius, 2011; Café Zuflucht, 2012; Schmidt, 2013), and often related to language or social barriers that make it difficult for this population to feel as if they belong in German society. Shilan F. stated that through her involvement in community activities and hobbies such as dancing, swimming and basketball, she was slowly able to feel more integrated after her asylum experience into Aachen (Sillius, 2011). These personal examples support the notion that informal health methods care such as activities and sports, can create a feeling of welcoming and belonging that is effective for combating the causes of mental health issues such as alienation and segregation, as explained by contestant enmity. If both cities, Toronto and Aachen, can utilize a similar approach to that laid out by Süssmuth (2009) regarding a two-way integrative approach which emphasizes responsibility for effective community cohesion on both community members and newcomers, through the use of activities and 
informal programs and spaces of welcome, it is possible to target the mental health needs of "tolerated" and non-status peoples. Acknowledging the Post-national rights of people living within the city would not only warrant, but require community level organizations and municipalities whom are best positioned to meet immediate needs, to act on behalf of "tolerated" or non-status peoples. In this case, action being the creation of supportive measures resulting in better mental health outcomes. Ensuring the human rights of these groups is a pressing concern that cannot be denied, especially if organizations adhere to the Post-national approach which would extend equal rights to all contributing to the communities in which they live. A Postnational outlook is beneficial not only in this extension of rights, but in terms of framing one's thinking to truly see these groups - placed precariously as 'out-groups' - as equal members or citizens of the city or nation. When one truly believes in that equality among groups living in the community regardless of status, then the preforming of duties in serving providing organizations, become less of a performance and more of a sincere expression of respect.

\section{The Importance of Identity Formation Theory:}

If community groups and organizations working with refugees, non-status peoples and “"'tolerated"" peoples truly understood the merit of the Symbolic Interactionist approach to the formation of identity, services could be geared with much more understanding of the small ways in which service users of these populations can be assisted. The need to understand the role of service providing organizations, in creating feelings of isolation or belonging, through their own interactions with service users is crucial in addressing the at risk mental health concerns resulting from migration. The structure of external factors such as regulations and prohibition of movement influence the identity formation of the individual and are enforced through institutional norms and imposed through society (Cinoğlu \& Arikan, 2012). Therefore if service 
providing institutions are simply accepting these norms and reproducing them through practices such as not fully understanding the legalities and logistics of non-status or "tolerated" peoples, or denying adequate service, then these organizations are perpetuating the feelings of isolation and fear which breed anxiety and depressive disorders. When an individual realizes that they cannot change the structures present in the host society, their behaviour is adapted to fit within these borders. This loss of self in favour of blending in can be counteracted by service providers who recognize that the structures in place are disempowering and daunting obstacles to non-status or "tolerated" people. With its emphasis on micro level interactions, Symbolic Interactionism as a form of identity formation proves crucial at the municipal service provision level, giving organizations the opportunity to assist in a healthy formation of identity in an effort to combat the onset of unhealthy self-perceptions brought on by present power structures. Further, to understand the ways in which these populations are disenfranchised through the various confusing legislations, and circumstantially based financial, employment and movement entitlements or restrictions, gives an opportunity to organizations to create programming that is sensitive and positively reinforcing in these specific areas. Service providing organizations need to work from a mandate that recognizes that mental health and stability mostly depend on the nature of the identities and self-perception of the individual, and therefore working to create healthy identities within the organization and community as a whole, will work to create healthy mental capabilities and strong coping mechanisms among non-status and "tolerated" peoples.

\section{Combatting municipally negative images of precarious migration:}

Moving forward to better service delivery relies not only on individual service providers, but also the municipal environment in which they operate. As supported through various research initiatives and policy reports, an approach involving equal effort from both the receiving society 
as well as newcomers, is the ideal way to create a welcoming and successful city (Süssmuth, 2009; Bhuyan, 2011). Sanctuary City is one small representation of a movement in the direction of breaking down the regulatory and systemic barriers in access to service, but serves only as a starting point for the ways in which cities need to commit to providing a safe environment for all within its borders, and showing public support for migrants that do not necessarily fall into the economic and business classes. Initiatives in both Canada and Germany aimed at recruiting these types of favoured migrants, create negative public images of migrants such as asylum seekers or over-stayers that do not fit this mold, and are further perpetuated by researchers claiming all of the negativities and ills that come with such unfavoured migratory movement (Birg, 2010; Richter, 2009; Focus Online, 2013). The perpetuation of the economic utility discourse needs to be overshadowed, specifically at the municipal level, by a discourse that is supportive of all that migrants have to offer to the city, not merely in tokenistic cultural ways, but in their ability to also be academically and professionally successful, and thus equally important members of the receiving cities of Toronto or Aachen. By relying solely on the achievements of highly qualified migrants, precarious newcomers are automatically deemed the "bad" migrant looking to take what the host country has to offer. Through the shift towards acknowledging the human perspective of precarious migrants - by perhaps municipally offered activities, sports and other events - the municipalities of Toronto and Aachen have the opportunity to create a sense of belonging that fosters good mental health and identity formation, creating economic and cultural gains for all parties involved - while informally turning what was once "tolerated", into something that is compassionately welcomed. 


\section{Works Cited}

Angendendt, S. (2007). Perspectives of German immigration policy. Freidrich Eburt Stiftung: Focus on Germany.

Bauder, H. (2011). Immigration Dialectic: Imagining community, economy and nation. Toronto: University of Toronto Press.

Bauer, T. K., Lofstrom, M., \& Zimmermann, K. F. (2001). Immigration policy, assimilation of immigrants and natives' sentiments towards immigrants: Evidence from 12 oecdcountries. The Center for Comparative Immigration Studies: Working Paper.

Becoming Neighbours. (2013). Goals of the becoming neighbours ministry. Retrieved from http://becomingneighbours.ca/our-goal/

Bhuyan, R. (2011) Negotiating Social Rights on the Frontlines of Service Delivery to Immigrants with Precarious Status. Paper presented at the annual meeting of the The Law and Society Association, Renaissance Chicago Hotel, Chicago, IL. 2013-06-10 from http://citation.allacademic.com/meta/p406450_index.html

Birg, H. (2010). Auswirkungen und Kosten der Zuwanderung nach Deutschland. Gutachen im Auftrag des Bayerischen Staatsministeriums des Innern.

Board of Health, (2011). The global city: Newcomer health in Toronto.

Retrieved from City of Toronto website: http://app.toronto.ca/tmmis/viewAgendaItemHistory.do?item=2011.HL9.1

Bradimore, A., \& Bauder, H. (2011). Mystery ships and risky boat people: Tamil refugee migration in the newsprint media. Canadian Journal of Communication, 36, 637-661.

Bundesagentur für Arbeit. (2012). Hartz IV bei Ausländer 2012

Bundesministerium der Justiz. (2012). Act on the residence, economic activity and integration of foreigners in the federal territory. Retrieved from website: http://www.gesetze-iminternet.de/englisch_aufenthg/residence_act.pdf

Café Zuflucht. (2012). Aktivitäten des Café Zuflucht 2012

Canadian Centre for Victims of Torture. (2013). Mental health. Retrieved from http://ccvt.org/programs/mental-health/ 
CAMH. (2013). Facts about depression and bipolar disorder. Retrieved from http://www.cmha.ca/mental_health/facts-about-depression-and-bipolar-disorder/

Cinoğlu, H., \& Arıkan, Y. (2012). Self, identity and identity formation: From the perspectives of three major theories. International Journal of Human Sciences, 9(2), 1114-1130.

City of Toronto, Executive Director, Social Development, Finance \& Administration. (2011). Staff report: Undocumented works in Toronto.

City of Toronto. Social Policy, Analysis \& Research Social Development, Finance \& Administration Division, (2013). Newcomer demographics. Retrieved from website: http://www.toronto.ca/newcomer/pdf/newcomer_demographics.pdf

Cohen, R. (2006). Migration and its enemies: Global capital, migrant labour and the nation state. Aldershot: Ashgate Publishing, Ltd.

Devoretz, D., Hinte, H., \& Werner, C. (2002). How much language is enough? Some immigration language lessons from Canada and Germany. Institute for the Study of Labor (IZA): Discussion Paper 555, 1-90.

Eckardt, F. (2007). Multiculturalism in Germany: From ideology to pragmatism- and back?. National Identities, 9(3), 235-245.

Elgersma, S. Library of Parliament, Political and Social Affairs Division. (2008). Immigration status and legal entitlement to insured health services. Retrieved from website: http://www.parl.gc.ca/content/LOP/ResearchPublications/prb0828-e.pdf

Federal Statistical Office of Germany, (2012). Statistical yearbook Germany: Extract | chapter 2 population, families, living arrangements. Retrieved from website: https://www.destatis.de/EN/Publications/Specialized/Population/StatYearbook_Chapter2 _5011001129004.pdf?_blob=publicationFile

Fenta, H., Hyman, I., \& Noh, S. (2006). Mental health service utilization by Ethiopian immigrants and refugees in Toronto . Journal of Nervous and Mental Diseases, 194(12), 925-934. Retrieved from http://libra.msra.cn/Publication/37683511/mental-healthservice-utilization-by-ethiopian-immigrants-and-refugees-in-toronto

Föbker, S., \& Temme, D. (2013, July). Competing for talent how do municipal policies in Germany contribute to attracting highly-skilled migrants?.Gronigen, Netherlands.

Focus Online. (2013, March 2). Hohe Kosten für Einwanderer: Zwei drittel der Deutschen wollen Zuwanderung begrenzen. Focus Online 
Ghassemi, E. (2013, April). The newcomer centre of peel. Placement seminar, Ryerson University, Toronto.

Gleichbehandlungsbuero. (2009). Gbb Aachen. Retrieved from http://www.gleichbehandlungsbuero.de/

Goldring, L., Berinstein, C., \& Bernhard, J. (2007). Institutionalizing precarious immigration status in Canada. Early Childhood Education Publications and Research, Retrieved from http://digitalcommons.ryerson.ca/cgi/viewcontent.cgi?article=1001\&context=ece

Kalter, F. \& Schulz, B. (2013). Stetiger Wandel über Generationen. Forschung. (pp.28-33)

Keung, N. (2013, February 21). Toronto declared 'sanctuary city' to non-status migrants. Toronto Star. Retrieved from http://www.thestar.com/news/gta/2013/02/21/cisanctuarycity21.html

Khanlou N. (2010). Migrant mental health in Canada. Canadian Issues, Summer, 9-16.

Kirmayer, L. J., Narasiah, L., Munoz, M., Rashid, M., Ryder, A. G., Guzder, J., Hassan, G., Rousseau, C., \& Pottie, K. (2011). Common mental health problems in immigrants and refugees: General approach in primary care. Canadian Medical Association Journal, 183(12), doi: 10.1503/cmaj.090292

McKenzie K, Hansson E, Tuck A, and Lurie S, for the Task Group of the Services Systems Advisory Committee, Mental Health Commission of Canada. (2009). Improving mental health services for immigrant, refugee, ethno-cultural and racialized groups: Issues and options for service improvement. Retrieved from website: http://www.mentalhealthcommission.ca/SiteCollectionDocuments/Key_Documents/en/20 10/Issues_Options_FINAL_English\%2012Nov09.pdf

Migration und Bevölkerung. (2013). Deutschland: 1,5 Millionen Menschen weniger als angenommen.Migration und Bevölkerung, 5, 1-3. Retrieved from http://www.migrationinfo.de/sites/migration-info.de/files/attachments/migration-und-bevoelkerung-201305.pdf

Newcomer Centre of Peel. (2013). Services. Retrieved from http://www.ncpeel.ca/services.html No One is Illegal. (2012). The wrongs of the Canadian immigration system. Retrieved from http://toronto.nooneisillegal.org/node/573

Pädagogische Zentrum Aachen (PAZ). (2013). Das Psychosoziale Zentrum für Flüchtlinge. Pro Asyl. (2011). Für eine neue Bleiberechtsregelung. Retrieved from 
http://www.proasyl.de/fileadmin/proasyl/fm_redakteure/Broschueren_pdf/ENDVERSIO N_Bleiberechtsbroschuere_2011_Web.pdf

Richter, C. (2013). Die Vermögensverteilung in Deutschland. Retrieved from CRP Infotec website: http://www.crp-infotec.de/01deu/finanzen/privat_vermoegen.html

Sassen, S. (2002). Towards post-national and denationalized citizenship. In E. Isin \& B. Turner (Eds.), Handbook of Citizenship Studies (pp. 277-291). SAGE Publications Ltd.

Schmidt, F. (2013, May 02). Ein Wettlauf der Schäbigkeit.Frankfurter Allgemeine

Schuehrer, J., Benke, E., Kravchik, V., di Marco, N., \& Akbal, E. (2013). Asylum in Germany: Guidelines for immigration. Retrieved from http://www.infoasyl.de.vu/

Serpe, R., \& Stryker, S. (2011). The symbolic interactionist perspective and identity theory. Handbook of Identity Theory and Research, doi: 10.1007/978-1-4419-7988-9_10

Sharma, N. (2007). Global apartheid and nation-statehood: Instituting border regimes. In J. Goodman \& P. James (Eds.), Nationalism and global solidarities (pp. 92-109). London: Routledge.

Sillius, S. (2011). Wie es sich anfühlt, ein Flüchtling zu sein.Aachener Zeitung. Retrieved from http://www.save-me-aachen.de/tl_files/dokumente/an_2011-03-147_janneteller-1.pdf

Simich, L. (2010). Health literacy, immigrants and mental health. Canadian Issues, Retrieved from http://www.metropolis.net/pdfs/immi_health/Immigrant Mental Health - pgs1722.pdf

Sitsabaiesan, R. (2012, March 15). In debate: Funding cuts to settlement services agencies.

Retrieved from http://rathikasitsabaiesan.ndp.ca/post/in-debate-funding-cuts-tosettlement-services-agencies

Soysal, Y. N. (1994). Limits of citizenship: Migrants and Postnational membership in Europe. University of Chicago Press.

Soysal, Y. N. (2012). Citizenship, immigration, and the European social project. The British Journalof Sociology, 63(1), 1-21. doi: 10.1111/j.1468-4446.2011.01404.x

Sozial Hilfe. (2013). Migranten und Hartz IV. Sozial Hilfe, Retrieved from http://www.sozialhilfe24.de/news/1034/migranten-in-der-hartz-iv-falle/

Stadt Aachen, (2006). Integrationskonzept der Stadt Aachen. Aachen, Germany:

Stadt Aachen. (2012). Bevölkerungsstand. Retrieved from website:

http://www.aachen.de/DE/stadt_buerger/aachen_profil/statistische_daten/bevoelkerungsst and/index.html 
Statische Bundesamt. (2011). Empfang von Regelleistungen. Retrieved from website:

https://www.destatis.de/DE/ZahlenFakten/GesellschaftStaat/Soziales/Sozialleistungen/As ylbewerberleistungen/Tabellen/RegelleistungenEmpfaenger.html

Statistische Ämter des Bundes und der Länder, (2013). Zensus 2011: 80,2 Millionen Einwohner lebten am 9. Mai 2011 in Deutschland. Retrieved from website: https://www.zensus2011.de/SharedDocs/Aktuelles/Pressemitteilung_des_Statistischen_B undesamtes.html?nn=3065474

Statische Bundesamt. (2013). Recipients of standard benefits. Retrieved from website: https://www.destatis.de/EN/FactsFigures/SocietyState/SocialStatistics/SocialBenefits/Be nefitsAsylumSeekers/Current.html

Statistics Canada. (2006). Immigration in Canada: A portrait of the foreign-born population, 2006 census. Retrieved from http://www12.statcan.gc.ca/census-recensement/2006/assa/97-557/p24-eng.cfm

Stets, J. E., \& Burke, P. J. (2003). A sociological approach to self and identity. In M. Leary \& J. Tangney (Eds.), The Handbook of Self and Identity. New York: Guildford Press.

Süssmuth, R. (2009). The future of migration and integration policy in Germany. Migration Policy Institute.

Tambini, D. (2001). Post-national citizenship. Ethnic and Racial Studies, 24 (2). 195-217 Uniya Jesuit Social Justice Centre. (2013). Overview of Canada. Retrieved from Uniya Jesuit Social Justice Centre website: http://www.uniya.org/research/asylum_canada.pdf von Stritzky, J. (2009). Germany's immigration policy: From refusal to reluctance. ARI: Demography, Populations and International Migrations, 93.

Wendland, S. (2011). Social Tensions and Acculturation: Portrayals of German Integration Discourse. Masters diss., Liberty University.

Winter, E. (2010). Trajectories of multiculturalism in Germany, the Netherlands and Canada: In search of common patterns. Government and Opposition,45(2), 166-186. 